\title{
25. BATHYMETRY AND REGIONAL TECTONIC SETTING OF THE LINE ISLANDS CHAIN'
}

\author{
Edward L. Winterer, Scripps Institution of Oceanography, La Jolla, California
}

\section{INTRODUCTION}

The Line Islands seamount chain (Plate 1) stretches southeast across the Central Pacific from the MidPacific Mountains to the equator, a total distance of about $3000 \mathrm{~km}$; widely spaced, isolated seamounts and ridges form a less well defined extension of the chain that continues another $1500 \mathrm{~km}$ southeastward to link up with the north end of the Tuamotu Chain (Mammerickx et al., 1974). The origin of this chain has been ascribed to motion of the Pacific plate over a more or less fixed melting anomaly or "hot spot" (Morgan, 1972a, b), and it was one of the principal objectives of Leg 33 to test this hypothesis. It is the purpose of this chapter to place the drilling results along the chain in their regional context. Bathymetric, magnetic, seismic, petrologic, and sedimentologic data gathered on expeditions of the Scripps Institution of Oceanography, both before and after Leg 33, along with unpublished bathymetric data collected by Lamont-Doherty Geological Observatory and the Hawaii Institute of Geophysics have been used in this synthesis.

\section{MORPHOLOGY}

The morphology of the Line Islands chain is complex, first because there are several distinct morphologic subdivisions along the chain, and second because there is a strong en echelon structure to the chain, in a direction parallel to another set of ridges and seamount chains that crosses the Line Islands chain at about a $45^{\circ}$ angle in an east-southeast direction-the Line Islands Cross Trend. Based on gross morphology, three geographic subdivisions can be recognized in the Line Islands chain: (1) The Northern Province, from the south edge of the Mid-Pacific Mountains at Horizon Guyot to the Clarion Fracture Zone; (2) the Central Province, from the Clarion Fracture Zone to the escarpment just north of Kingman Reef; and (3) the Islands Province, from Kingman Reef to about $2^{\circ} \mathrm{S}$. Each of these subdivisions will be described in turn below. Cross Trend chains intersect the west side of the Line Islands chain in each of the three provinces: (1) at $14^{\circ}-16^{\circ} \mathrm{N}$ in the Northern Province; (2) at $9^{\circ}-10^{\circ} \mathrm{N}$ in the Central Province; and (3) at about $1^{\circ} \mathrm{N}$ to $1^{\circ} \mathrm{S}$ in the Islands Province. Because the Cross Trend chains are so closely tied to the Line Islands chain geographically and structurally, they also will be described in some detail below.

\section{Northern Province}

The deep-water passageway just south of Horizon Guyot marks the northernmost limit of the Line Islands

\footnotetext{
'This chapter includes a new Bathymetric Chart of the Line Islands Region by Edward L. Winterer and Jacqueline Mammerickx.
}

chain as a distinct morphologic feature. Although short bathymetric trends parallel to the Line Islands trend are contoured within the Mid-Pacific Mountains northwest of Johnston Island, the most prominent lineations in this region are almost exactly at right angles to the Line Islands trend. In the Northern Province, the chain consists of a row of long, narrow, straight to broadly arcuate ridges along the east side of the chain and a series of shorter subparallel ridges about $150 \mathrm{~km}$ to the west. The ridges rise from a sea floor about 5000-5500 meters deep to summits typically around $1500-2000$ meters.

At the north end of the Northern Province, the Line Islands chain begins with a narrow eastern ridge about $500 \mathrm{~km}$ long and less than $100 \mathrm{~km}$ wide, having a summit level of about 2000 meters, with a few peaks rising to around 1800 meters. Johnston Island is a coral atoll atop an isolated seamount along the west side of the chain. Between $15^{\circ}$ and $16^{\circ} \mathrm{N}$, a series of en echelon ridges marks the intersection of a Cross Trend chain with the Line Islands chain. One of the Cross Trend ridges gradually arcs more and more southeasterly to become a Line Islands trend ridge along the east side of the chain, and this narrow ridge continues southward for about $400 \mathrm{~km}$, to a deep passage through the chain along the prolongation of the Clarion Fracture Zone. Another set of en echelon ridges at about $13^{\circ}-14^{\circ}$ parallels the northern Cross Trend group and is separated from it by a trough about 5300 meters deep. The individual ridges in these en echelon groups tend to be oriented parallel to the Line Islands trend, while the group has the Cross Trend. The bathymetry of one of the smaller, western ridges, which was surveyed and dredged (Natland, this volume) during Scripps expedition Seven-Tow, Leg 6, is shown in Figure 1. Some of the ridges are capped with a thin layer of pelagic sediments resting on a gently rounded summit (Figure 2 ), whereas others are barren of sediment. Numerous attempts were made during Scripps Expedition SevenTow, Leg 6, to dredge the break in slope on ridges with flattish summits in the hope of finding coral or other evidence of shallow water conditions, but the dredges recovered only volcanic rocks or pelagic sediments. The sediment thickness on the deep sea floor outside the northern part of the chain, both to the east and west, is about 300 meters $(0.3 \mathrm{sec})$, whereas in the valleys between ridges within the chain, the sediment thickness increases to as much as 700 meters $(0.7 \mathrm{sec})$ (Figure 3). The abnormal thickness of the sediments in the deepwater valleys between ridges (e.g., at Site 314) suggests the possibility of turbidites of shallow-water origin. Short of another drilling attempt at Site 314 or on Johnston Island, the most reliable way to place a minimum age on the cessation of volcanism at the north end of the Line Islands chain may be through continued efforts to dredge shallow-water fossils from the ridge tops. 


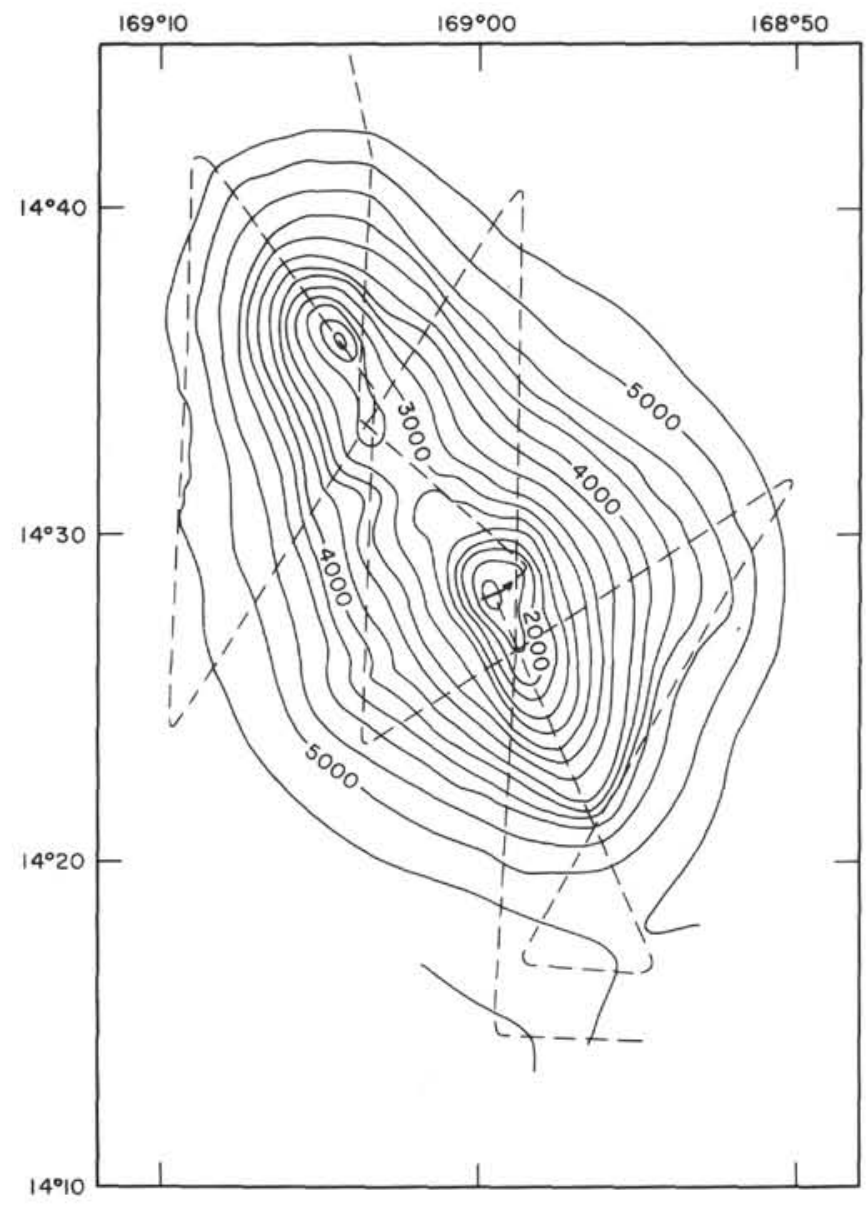

Figure 1. Bathymetric chart of a seamount in the Northern Province of the Line Islands Seamount chain, surveyed during Scripps Institution of Oceonography Cruise SevenTow, Leg 6, using $R / V$ Thomas Washington. The trend of this seamount is parallel to the general trend of the Line Islands chain. No sediments were seen on reflection profiler records on the seamount, but a large haul of igneous rocks, including quartz trachytes and hyaloclastites, were recovered in the dredge haul taken near the summit. Their petrology and chemistry is described by Natland (this volume). Contours in meters, corrected for the velocity of sound in water according to Matthews' tables (1944). Location of dredge station Seven-Tow-137D shown by arrow. Ship's track shown by dashed lines.

\section{Central Province}

Although the Clarion Fracture Zone cannot be traced with certainty into the Line Islands chain, there is a morphologic change at about the extrapolated crossing point, which corresponds with the position of the deepest pass through the chain $(\sim 5250 \mathrm{~m})$. South of this pass for about $600 \mathrm{~km}$, the Line Islands chain consists of several parallel rows of more-or-less isolated seamounts. Most of these have summit depths between 1000 and 1500 meters; one peak rises to 650 meters. JOIDES Site 165 is located west of the Central Province, about $50 \mathrm{~km}$ from one of the guyots in the Line Islands chain. The sea floor is several hundred meters shallower in this central

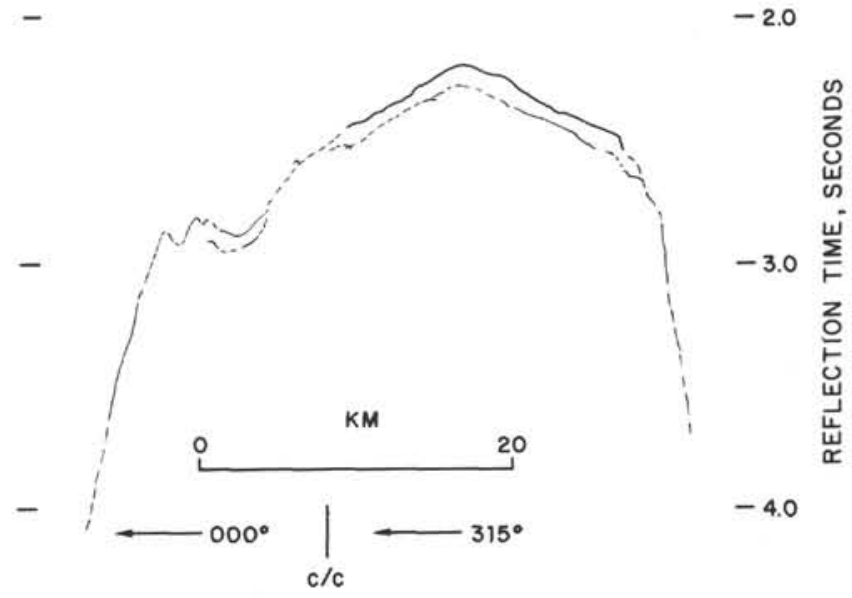

Figure 2. Line drawing of a seismic reflection profiler record obtained from $R / V$ Thomas Washington during Scripps Institution of Oceanography Cruise Seven-Tow, Leg 6, showing a crossing near the north end of the long ridge along the east side of the Northern Province of the Line Islands Seamount chain. A thin cover of pelagic sediments caps the ridge at this place. A dredge haul obtained nearby from the flanks of this ridge recovered trachyte (Natland, this volume).

area than in the Northern Province, and seismic reflection profiles (Figure 4) show that basement is correspondingly shallow here also, perhaps because of more voluminous outpourings of lava here than farther north.

Two of the seamounts in this province were surveyed during the SIO Expedition Seven-Tow, Leg 6, and their bathymetry is shown in Figures 5 and 6 . The more northern seamount is quite conical and shows no evidence of a flat top. A dredge from the summit recovered volcanic rocks encrusted with manganese with included planktonic foraminifers of Campanian or Coniacian age (identified by the late E.C. Allison). The more southerly of the surveyed seamounts has a flattish sediment-covered area at about 1500 meters depth, partly rimmed by narrow ridges about 200 meters high, suggestive of caldera rims (Natland et al., 1972). Seismic reflection profiles of two other seamounts on the western side of the central province (Figure 7) show flattish summits capped by thin mounds of pelagic sediments.

The seamounts in the Central Province are aligned in three rows parallel to the overall trend of the Line Islands chain, and there may be a fourth row about 150 $\mathrm{km}$ farther east. A fifth parallel row of seamounts stands another $400 \mathrm{~km}$ farther east.

Between the isolated seamounts in the Central Province the sea floor is deep enough to have permitted the flow of bottom waters across the Line Islands chain. The evidence for this flow is provided by reflection profiler records showing erosion of sediments in the passes (Schlanger and Winterer, this volume). Those bottom currents probably flowed eastward through the passes from the Central Basin and may have continued farther east, guided by Cross Trend ridges and eroding bottom sediments (Normark and Spiess, in press). 


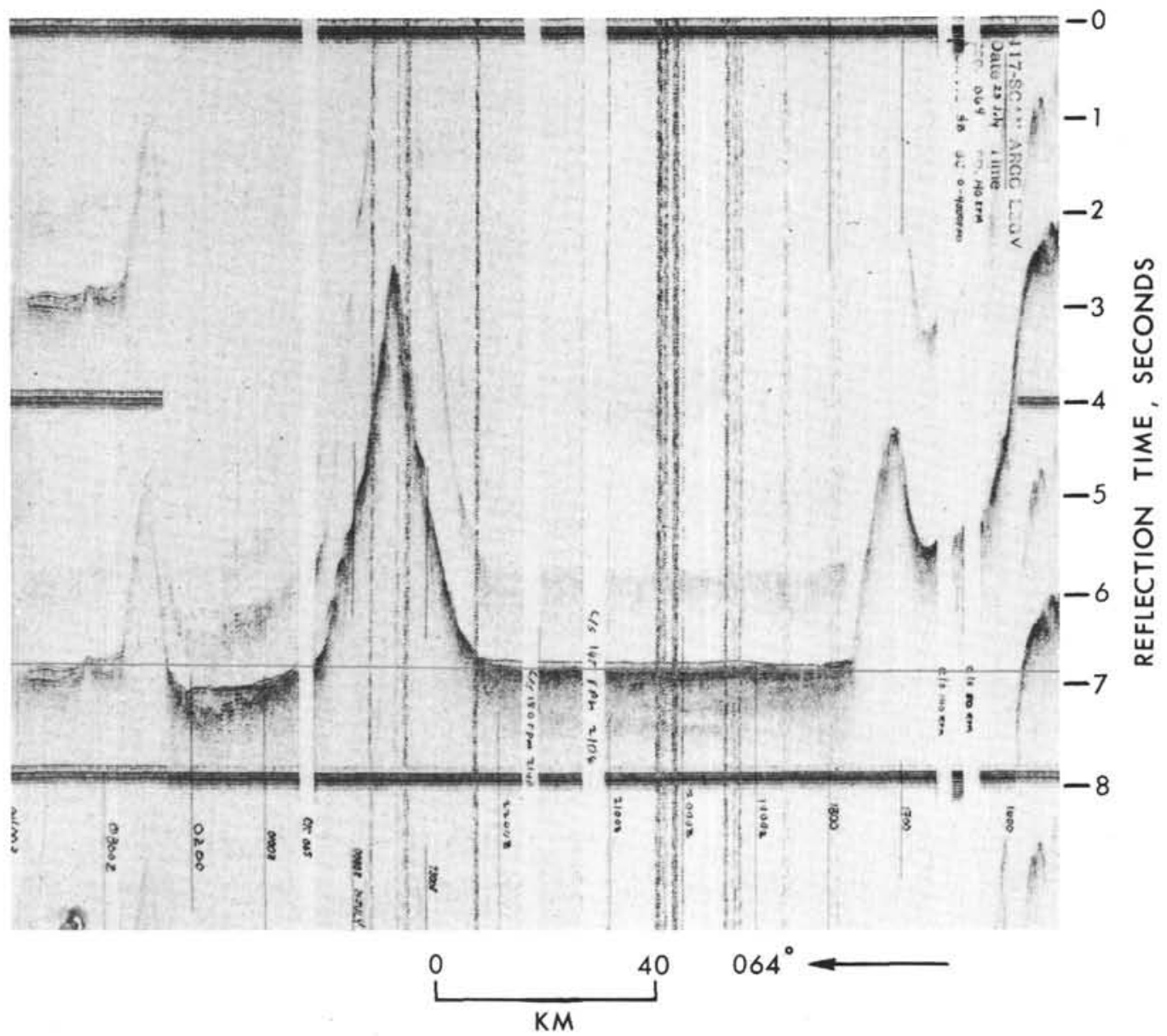

Figure 3. Seismic reflection profiler record obtained from $R / V$ Argo during Scripps Institution of Oceanography Cruise Scan, Leg 5, showing a profile across the Northern Province of the Line Islands chain about $2 \mathrm{~km}$ north of DSDP Site 314 (see the track chart in the Site 314 Chapter, this volume, for the exact location of the track). The valley in which Site 314 lies contains about 700 meters of sediment, which is much greater than the thickness of sediment farther east and suggests that redeposited sediments from the adjacent ridges may be a significant component in the stratigraphic column in the valley.

The Central Province is the most conspicuous locus of the intersection of the Line Islands chain with the Cross Trend. The line of ridges that intersects the Line Islands chain at $10^{\circ} \mathrm{N}$ can be traced with certainty for some 500 $\mathrm{km}$ to the west of the Line Islands chain, and clusters of seamounts on the same alignment can be identified for another $2200 \mathrm{~km}$ to the north-northwest, through Dixon Guyot to $175^{\circ} \mathrm{E}, 14^{\circ} \mathrm{N}$ (Winterer, 1973, plate I; Chase et al., 1971). A small seamount on this Cross Trend chain was surveyed and dredged during SIO Expedition Seven-Tow, Leg 6, and a detailed bathymetric chart of the seamount is shown in Figure 8.

East of the Line Islands chain, this same Cross Trend chain can be traced another $800 \mathrm{~km}$, to a twin-peaked seamount at $9^{\circ} \mathrm{N}, 158^{\circ} \mathrm{W}$. The detailed bathymetry of this seamount is shown in Figure 9.

About $150 \mathrm{~km}$ to the south of this prominent Cross Trend chain is another parallel chain of seamounts and ridges that can be recognized for several hundred $\mathrm{km}$ both east and west of the Line Islands chain.

\section{Islands Province}

Beginning at Kingman Reef, the morphology of the Line Islands chain changes abruptly from rows of isolated seamounts to a massive structure from 150 to 300 $\mathrm{km}$ in width, comprising closely packed ridges and cones. Coral reefs surmount five of these ridges at Kingman Reef, Palmyra Island, Washington Island, Fanning Island, and Christmas Island. The ridge is widest in the north and narrows rather suddenly from 300 to 150 $\mathrm{km}$ just north of Washington Island. From Christmas Island south to about $2^{\circ} \mathrm{S}$, the chain comprises a main eastern ridge and a narrow western ridge, broken into short en echelon elements. The eastern ridge dies out at about $2^{\circ} \mathrm{S}$, but the western alignment can be traced discontinuously to Malden Island at $4^{\circ} \mathrm{S}$. The boundary between the Islands Province and the next province to the south is quite arbitrarily placed at about $2^{\circ} \mathrm{S}$, where the main ridge dies out. From there northward to Kingman Reef, the main ridge forms a continuous structure 


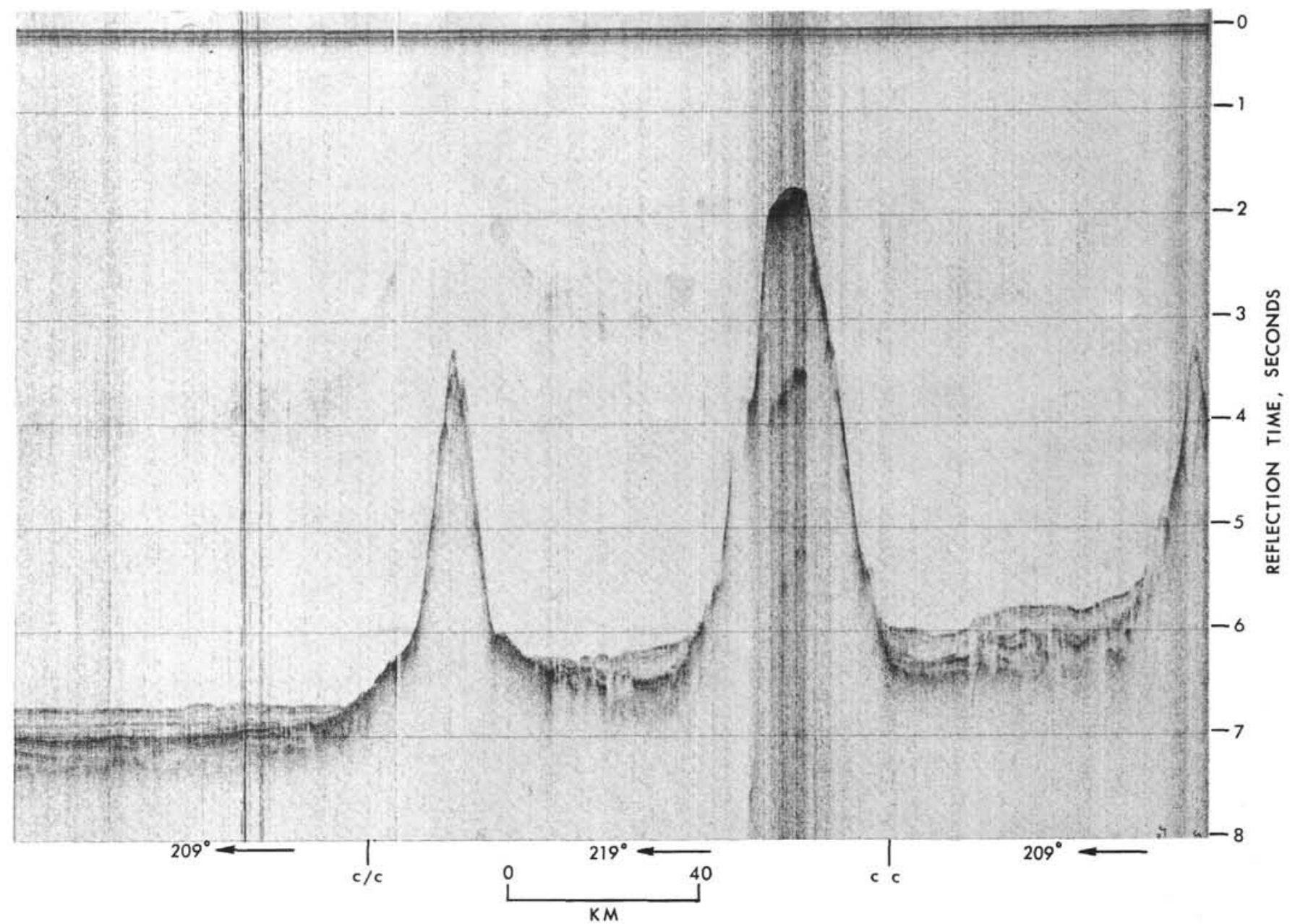

Figure 4. Seismic reflection profiler record across part of the Central Province of the Line Islands chain, near DSDP Site 165, obtained from $R / V$ Glomar Challenger during Leg 17, and showing the coalescing of volcanoes that results in a shallowing of regional basement.

shallower than 3500 meters, and from Christmas Island to Kingman Reef, the ridge is everywhere shallower than 3000 meters.

The general foundation on which the Islands Province stands is shallower than the regional sea floor. A broad arch, with a crest at about 4500 meters depth, and with a trend nearly parallel to the Cross Trend, intersects the Line Islands chain beneath the Islands Province. The crest of the arch can be traced from a point about 500 $\mathrm{km}$ west of Kingman Reef southeastward to the middle part of the Islands Province. A possible continuation of the arch can be followed eastward at least as far as about $150^{\circ} \mathrm{W}$, at the equator.

Two trends are dominant in the Islands Province: The Main Line Islands trend and the Cross Trend. From Washington Island southward, most of the higher ridges, including the ridges surmounted by Washington, Fanning, and Christmas islands, are aligned parallel to the Cross Trend, and the Main Line Islands here consist largely of an en echelon arrangement of these Cross Trend elements. Some individual ridges, for example, the ridge northeast of Washington Island, are parallel to the Line Islands trend.

A more detailed picture of part of the chain between Washington and Fanning Islands is shown in Figure 10, based on data gathered during SIO Expedition Eurydice, Leg 2, in the fall of 1974. The two trends are most conspicuous at Fanning Island, an atoll whose orientation is most likely a compromise between bedrock structure and the shaping effects of the prevailing Southeast Trades.

The en echelon ridges near Fanning Island are paralleled by deep, sediment-filled valleys. One of these valleys, southwest of Fanning Island, has been incised by a deep and narrow submarine canyon (Figure 10). Seismic reflection profiler records across the main ridge between Fanning and Washington Islands show a thick $(>1.0 \mathrm{sec})$ sediment fill in a wide en echelon intermontane valley atop the main Line Islands ridge (Figure 11). Sediment fill has subdued the original relief of the volcanic basement, and thus partly obscured the internal structure of the main ridges.

The three more-or-less isolated volcanoes west of the main ridge near Fanning Island are aligned parallel to the Line Islands trend, but are connected to the main ridge by narrow necks. East of the main ridge, a volcanic ridge trends almost at right angles to the main trend.

Available bathymetric control is not dense enough across the widest part of the Islands Province, north of Washington Island, to be certain of the trends of in- 


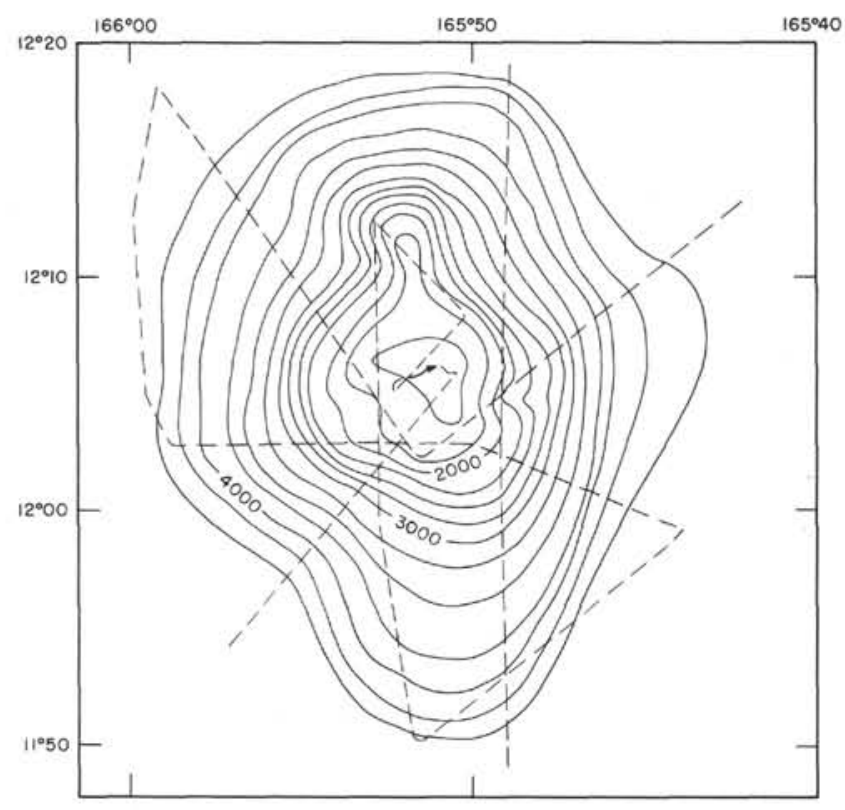

Figure 5. Bathymetry of a small seamount at the north end of the Central Province of the Line Islands chain, surveyed by $R / V$ Thomas Washington during Scripps Institution of Oceanography Cruise Seven-Tow, Leg 6. Several varieties of alkalic basalt were dredged at Station 133-D (Natland, this volume) and in the crevices of the manganese encrusted volcanic rocks were foraminifers, including Globotruncana linneiana, Rugoglobigerina sp., Heterohelix sp., Globotruncana concavata (?), Globotruncana fornicata (?), Globotruncana calcerata (?), and Marsonella oxycona, which the late E. C. Allison identified and assigned to the Late Cretaceous (Senonian). Other cavities in the rocks contained foraminiferal assemblages of late Paleocene-Eocene, Eocene, and late Miocene-early Pliocene age. The location of the dredge station is indicated by an arrow. Contours in meters, corrected for the velocity of sound in water according to Matthews' tables (1944). Ship's track shown by dashed lines.

dividual features. The data will permit contouring that emphasized the en echelon Cross Trend more than the contouring shown on Plate 1, which emphasizes northeast trends, at right angles to the Main Line Islands trend.

Cross Trend ridges extend south-southeast for about $600 \mathrm{~km}$ from the northern part of the Central Province. These ridges and seamounts have not been surveyed in detail, and it is not yet possible to say whether they are continuous structures or aligned isolated features. There is some suggestion of a secondary alignment of Cross Trend peaks in a direction parallel to the Line Islands trend. The track of Glomar Challenger between Sites 314 and 315 on Leg 33 crossed several of the Cross Trend ridges near their intersections with the Line Islands Ridge, and the form of the ridges projecting through a thick pile of pelagic and turbidite sediments is shown in the reflection profiler records (Schlanger and Winterer, this volume).

From Washington Island, at about $5^{\circ} \mathrm{N}$, to Christmas Island, at $2^{\circ} \mathrm{N}$, Cross Trend ridges are not recognized except for the en echelon ridges within the Line Islands Ridge.

West of Christmas Island, the main Line Islands Ridge is indented by a deep valley trending eastnortheast, which is a continuation of the bathymetric trends associated with the Nova-Canton Trough, 1000 $\mathrm{km}$ to the southwest. No evidence for a continuation of these Nova-Canton trends can be seen in the bathymetric or seismic profiler data east of the Line Islands. Christmas Island itself surmounts an en echelon ridge with Cross Trend orientation within the Line Islands Ridge. This ridge can be traced southeastward from Christmas Island for about $150 \mathrm{~km}$, and it is aligned with a similarly oriented row of seamounts or ridges several hundred $\mathrm{km}$ farther southeast, near the equator between $150^{\circ}$ and $154^{\circ} \mathrm{W}$.

East of Christmas Island, the Clipperton Fracture Zone can be recognized on seismic profiler records as far west as $153^{\circ} \mathrm{W}$, but its continuation any farther west than that is not evident in the data now available.

From Christmas Island southward to about $2^{\circ} \mathrm{S}$, morphology is similar to that in Northern Province, with a continuous eastern ridge-here comprising en echelon elements with trends parallel to the Cross Trend-and an en echelon set of shorter narrow ridges on the west, separated from the eastern ridge by a deep sediment-filled trough, where Site 316 was drilled. The western set of ridges can be traced south to Malden Island, a coral island which surmounts the east end of a $200-\mathrm{km}$-long ridge with a trend parallel to the Cross Trend.

A chain of seamounts aligned in the Cross Trend direction intersects the Line Islands Ridge near its southern termination. The chain, which is about $200 \mathrm{~km}$ wide, includes the en echelon ridges at the south end of the Line Islands Ridge, Jarvis Island, the seamounts just east of JOIDES Site 66, and probably the seamount group near $6^{\circ} \mathrm{N}, 174^{\circ} \mathrm{W}$, southeast of Magellan Rise. A bathymetric chart of one of the seamounts near JOIDES Site 66 is shown in Figure 12. Where this chain crosses the Nova-Canton Trough, there are large seamounts, and on the north side of the trough the seamounts are connected by a long narrow ridge parallel to the trough.

\section{Possible Southward Extension of Line Islands Chain}

From Malden Island to the north end of the Tuamotus, a double row of widely spaced seamounts, including Starbuck, Vostok, Flint, and Caroline Islands, delineate a possible continuation of the Line Islands chain (Mammerickx et al., 1974). This region is poorly surveyed and unsampled, and the relationship to the rest of the Line Islands chain may be genetic or only a fortuitous alignment. A fairly deep trough (about $5200 \mathrm{~m}$ deep), trending a little east of north separates Malden and Starbuck Islands from the rest of the seamounts farther to the southeast. The trend of this trough is at about right angles to the Cross Trend.

\section{Summary of Morphology}

The similarities in morphology along the Line Islands chain are more striking than the differences. Everywhere the chain comprises at least two parallel lines of seamounts or ridges, generally about $100 \mathrm{~km}$ apart. In most 


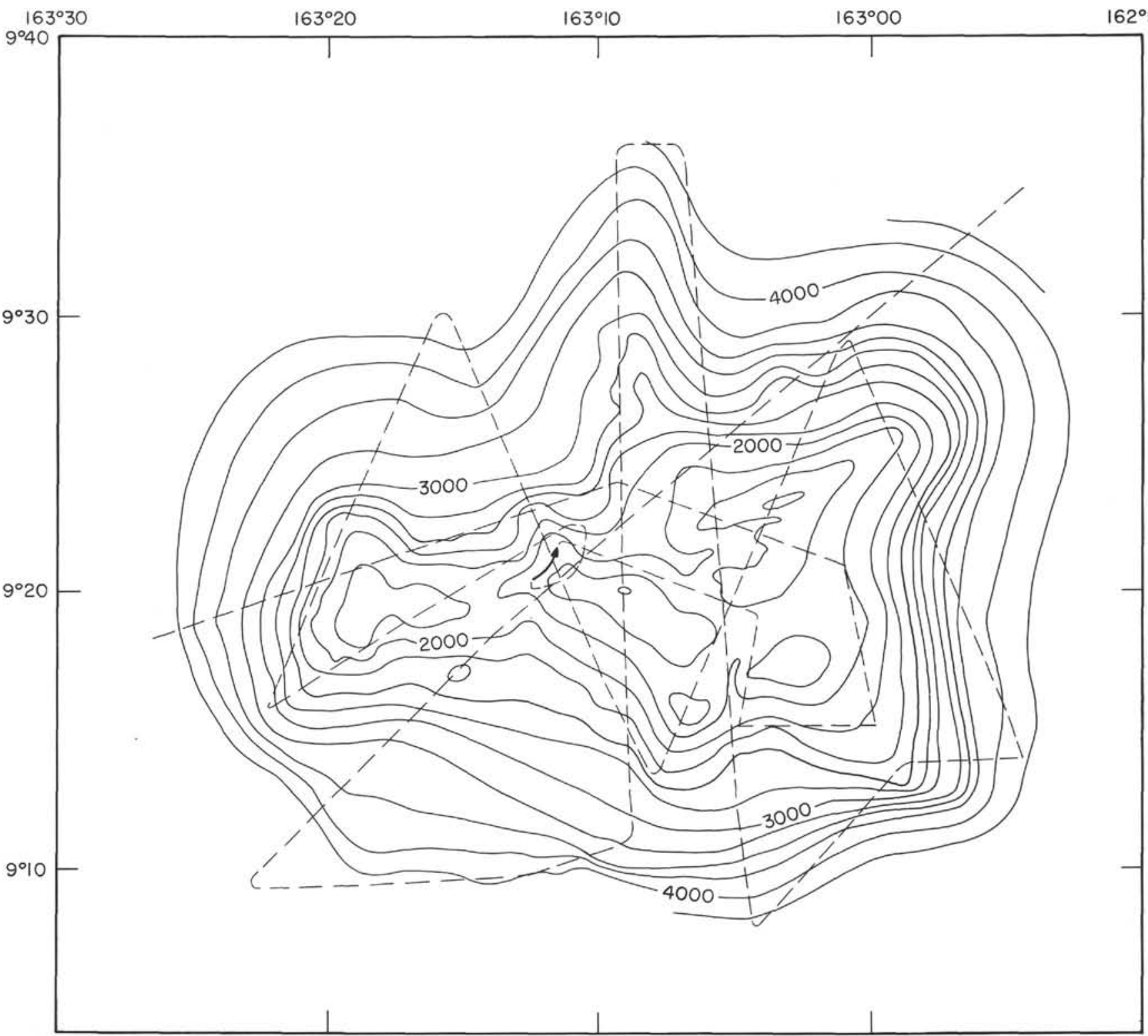

Figure 6. Bathymetric chart of a seamount in the Central Province of the Line Islands chain, surveyed by $R / V$ Thomas Washington during Scripps Institution of Oceanography Cruise Seven-Tow, Leg 6. The flattish summit area has a topography suggestive of caldera collapse features. Seismic reflection profiler records show thin $(\sim 100 \mathrm{~m})$ pelagic sediments in swales on the summit region. A dredge (Seven-Tow-129D) recovered potassic nephelinites and hyaloclastites (Natland, this volume) and calcareous ooze containing middle Eocene planktonic and benthonic foraminifers (personal communication, E. C. Allison) caught in a crevice between one of the volcanic rock fragments and its encrusting coat of manganese oxides. Location of dredge station $129 \mathrm{D}$ shown by arrow. Contours in meters, corrected for the velocity of sound in water according to Matthews' tables (1944). Ship's tracks shown by dashed lines.

places, the western row is discontinuous, whereas the eastern ridge, except in the Central Province, is nearly continuous. The width of the Line Islands chain increases to nearly $300 \mathrm{~km}$ in parts of the Islands Province, but the actual width of the belt of volcanism showing Line Islands trends may be as much as $1000 \mathrm{~km}$.

En echelon ridges aligned nearly parallel to the Cross Trend are common in all three provinces and are especially well developed in the best-surveyed parts of the Islands Province. Ridges and seamounts in the Cross Trend itself are similar morphologically to those in the
Line Islands in size and depth of summits. Line Islands trends are recognizable in the morphology and secondary alignments of Cross Trend ridges.

\section{REGIONAL GEOLOGIC SETTING OF LINE ISLANDS CHAIN}

The relationship of the Line Islands chain to its surroundings must be inferred mainly from bathymetric and from widely scattered drill-hole data. Magnetic anomalies associated with early Mesozoic sea-floor spreading are recognizable to the west of the Line 


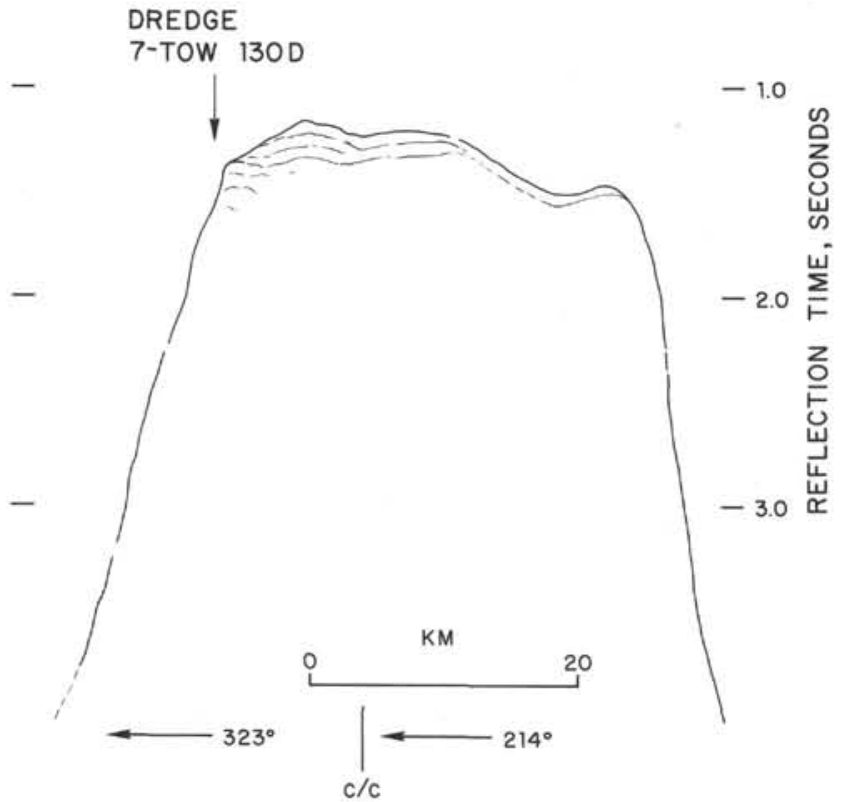

Figure 7. Line drawing of a seismic reflection profiler record taken by $R / V$ Thomas Washington on Scripps Institution of Oceanography Cruise Seven-Tow, Leg 6, across a seamount along the west side of the Line Islands chain, about $50 \mathrm{~km}$ east of DSDP Site 165. A thin cover of pelagic sediments drapes over the flattish summit area. A dredge at Station $130 D$ recovered alkalic basalt and hyaloclastites (Natland, this volume) with planktonic forminifers of middle Eocene age in ooze in seams in the manganese-encrusted volcanic rocks, according to the late E. C. Allison. The dredge station was close to the place indicated on the profile, but off the line of section. At DSDP Site 165, reefal debris of late Cretaceous and Eocene age were sampled in turbidites presumably derived at least in part from this flat-topped seamount (Winterer, Ewing, et al., 1973).

Islands in the Phoenix anomalies (Larson et al., 1972; Larson and Chase, 1972); and to the north in the Hawaiian Anomalies, (Larson and Chase, 1972), but most of the region around the Line Islands is magnetically quiet. This may be because the oceanic crust was formed during the Magnetic Quiet Era, in Middle and Late Cretaceous times, or because massive outpourings of plateau lavas at the time of spreading produced a thick crust with no net magnetic anomaly, or because older sea floor with magnetic anomaly patterns was flooded and buried by later lavas. The relatively low magnetic paleolatitude of the region in Late Cretaceous times prevents certain recognition of magnetic anomaly 32 in the region east of the Line Islands.

\section{Phoenix Lineations and Nova-Canton Trough}

The Phoenix magnetic anomaly set, which can be traced eastward toward the Line Islands to about $170^{\circ} \mathrm{W}$ (Larson et al., 1972) is paralleled along its south edge by a band of lineated sea floor. The most prominent feature in this bathymetric pattern is Nova-Canton Trough (Rosendahl, 1972), but smaller scale features with the same trend can be identified and contoured from echo sounder and seismic profiler records. From new soundings obtained during SIO Expedition Eurydice, Leg 2, Nova-Canton Trough can now be traced eastward as a series of slightly en echelon features all the way to the Line Islands. The en echelon pattern may be the result of offsets of the trough and associated ridges along cross faults. North of the trough, parallel lineations are established near $4^{\circ} \mathrm{N}, 164^{\circ} \mathrm{W}$, where a detailed survey was made during a seismic anisotropy study. Survey lines are likewise sufficiently dense in the area around $1^{\circ}-3^{\circ} \mathrm{N}$ and $160^{\circ}-163^{\circ} \mathrm{W}$ to recognize the "Phoenix" lineation in the bathymetry. Seismic reflection profiler records across the thick sediment apron southwest of Washington and Fanning Islands show basement relief features with the same trend as the features farther west, where the sediment cover is too thin to mask the structural relief.

A possible transform fault is recognizable in the offset of a Nova-Canton Ridge at $1^{\circ} \mathrm{N}, 161^{\circ} \mathrm{W}$, and again in a steep ridge trending a little east of south at $4^{\circ} \mathrm{N}, 162^{\circ} \mathrm{W}$. A reflection profiler record passing between these two points shows an offset in the basement.

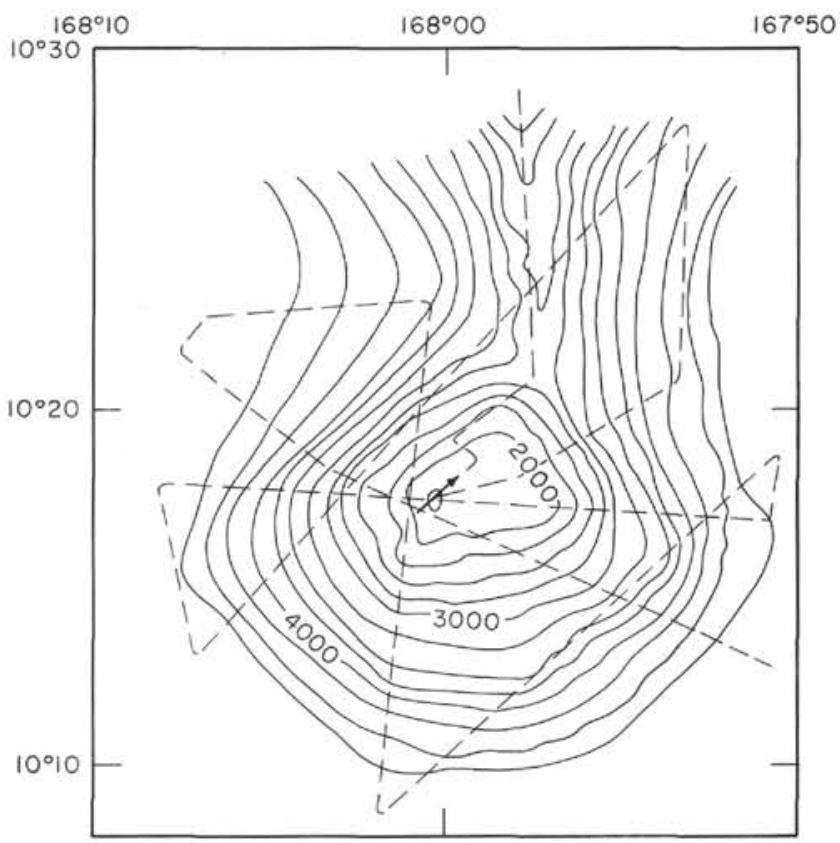

Figure 8. Bathymetric chart of a small seamount in the Cross Trend, about $250 \mathrm{~km}$ west of the Central Province of the Line Islands chain, surveyed by $R / V$ Thomas Washington during Scripps Institution of Oceanography Cruise Seven-Tow, Leg 6. A dredge from the location indicated by an arrow (Station 134D) recovered nephelinites and hyaloclastite (Natland, this volume) and foraminiferal limestone as partings within and beneath manganese coatings on the igneous rocks and as angular clasts in phosphorite-cemented breccias. The foraminifers, which were mainly planktonic types, were examined by the late E. C. Allison, who assigned the oldest of them an age of (?) middle Eocene. Contours in meters, corrected for the velocity of sound in water according to Matthews' tables (1944). Ship's track shown by a dashed line. 




Figure 9. Bathymetric survey of a large twin-peaked seamount in the Cross Trend, about $600 \mathrm{~km}$ east of the Central Province of the Line Islands chain, surveyed by $R / V$ Thomas Washington during Scripps Institution of Oceanography Cruise SevenTow, Leg 6. Profiler records a thin layer $(\sim 100 \mathrm{~m})$ of pelagic sediments draped across the flattish summit areas of both volcanoes. A dredge recovered from the western edge of the western volcano, at the location shown by an arrow at Station $128 D$, contained mugearite and hyaloclastites. Planktonic foraminifers, picked out of cavities between the volcanic rocks and the thick (up to $7 \mathrm{~cm}$ ) coat of manganese, are mainly of late Miocene to early Pliocene age, according to the late E. C. Allison. Soundings in meters, corrected for the velocity of sound in seawater according to Matthews' tables (1944). Ship's track shown by dashed lines.

South of Nova-Canton Trough, the bathymetric sounding data can be most easily contoured as parallel to the trough, although no detailed survey data are available. The pattern is interrupted by Manihiki Plateau, which cuts sharply across the "Phoenix" pattern as if it were a younger feature.

The age of the youngest anomaly (M-1) in the "Phoenix" magnetic lineation set is 110-115 m.y. (Larson and Chase, 1972), and the age of the crust on the younger Manihiki Plateau as determined at Site 317, drilled on this leg, is at least as old as early Aptian, and may be Barremian (107-116 m.y.). There is thus only some $8 \mathrm{~m} . y$. at the maximum in which to generate the crust between anomaly M-1 and the Manihiki Plateau. The total width of crust formed during this time was about $700-800 \mathrm{~km}$, yielding a half-rate of about 10 $\mathrm{cm} / \mathrm{yr}$, which is just about double the rate for the Phoenix magnetic set (Larson and Chase, 1972). Such a fast rate is also difficult to harmonize with the extraordinary relief of Nova-Canton Trough. If we assume, on the other hand, that the spreading rate for the Phoenix anomaly set continued during the formation of the sea floor adjacent to the Nova-Canton Trough, then we are led to the hypothesis that the trough is an abandoned or jumped spreading ridge, and that the sea floor south of the trough is a trapped piece of the Phoenix plate. This would imply the existence of magnetic anomaly $\mathrm{M}-1$ on this plate at about 300 or $400 \mathrm{~km}$ south of and parallel to Nova-Canton Trough; and indeed, a candidate for this anomaly can be recognized in the region around $4^{\circ} \mathrm{S}$, $162^{\circ} \mathrm{W}$ (Larson and Chase, 1972, fig. 3). The hypothesis that Nova-Canton Trough is an abandoned spreading center may also account for its astonishingly great depth $(>7500 \mathrm{~m})$ and the relief of the adjacent ridges, if we allow for a time of very slow spreading as the ridge died. Under this hypothesis, the age of Nova-Canton Trough would be about 6 m.y. younger than anomaly M-1, say 105-110 m.y. Under the hypothesis of continuous but speeded-up spreading, the age would be older by about 3 m.y. The difference is probably too slight for discrimination by either radiometric or paleontologic dating methods.

Data from JOIDES Site 66 (Winterer, Riedel, et al., 1971), drilled within the band of "Phoenix" lineation crust north of the Nova-Canton Trough, are at first glance in conflict with the Early Cretaceous age predicted for crust in this area. The drill encountered highly altered (alkalic?) basalt beneath very sparsely fossiliferous (radiolarian) pelagic clay. No calcareous sediments were recovered. The age of the radiolarians was Turonian or Cenomanian (87-100 m.y.). The anomalously young age of basement at this site may be (1) because older crust has been buried beneath younger volcanics, perhaps related to the Line Islands or Cross Trend chain volcanics-there is a cluster of Cross Trend seamounts close by-or (2) because the site is on an old buried hill and was kept clear of sediments until 10 or 20 m.y. after formation of the crust at a rise crest. 


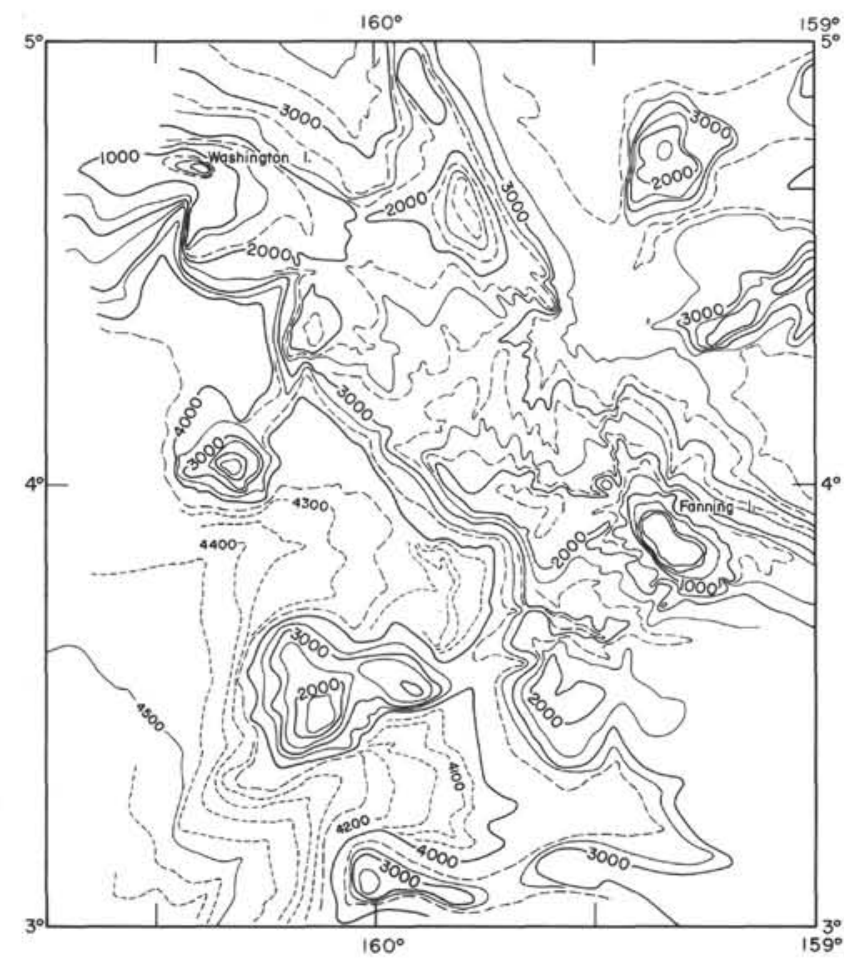

Figure 10. Bathymetric chart of a part of the Line Islands Ridge near Fanning Island. Contours in meters corrected for the velocity of sound (Matthews, 1944). Contours: 500 meters (solid), 250 meters (dashed), 50 meters (short dashed).

\section{Relations Between the Phoenix-Canton \\ and Hawaiian Lineations and Line Islands Chain}

The Line Islands chain cuts across and terminates the Nova-Canton Trough lineations. This is, of course, not surprising in view of the ages of rocks in the two trends: The oceanic crust in the Phoenix-Canton set is at least $105-110$ m.y. old, whereas the cessation of volcanism in the Line Islands, near the intersection, is about 85 m.y. The age relationship would be unequivocal if the Phoenix lineations could be recognized emerging from beneath the Line Islands on the east side, but the bathymetric and reflection profiler data do not reveal any simple continuation. Any former eastward continuation must either be buried beneath younger lavas or have been captured onto the Farallon plate and destroyed at a subduction zone against the Americas. Another possibility is that there never was any straightline continuation of Nova-Canton Trough, but rather that there was a junction between the Phoenix and Hawaiian lineations where the trough intersects the Line Islands Ridge, just north of Christmas Island. This would be a triple junction among the Pacific, Farallon, and Phoenix plates. The fact that the trend of the Line Islands Ridge is essentially parallel to the trend of anomaly M-1 in the Hawaiian anomaly set opens the possibility that the Line Islands chain occupies the site of a former spreading ridge, active in Early Cretaceous times. The relative spreading rates on the younger parts of the Phoenix and Hawaiian lineation sets (1.0/0.55) (Larson and Chase, 1972), taken together with the trends of the two lineations, yields a set of intersection angles whose locus would be a line trending northwest along the broad Cross Trend Arch, extending westnorthwest from Washington Island. The arch would be the expression of the western bight of this triple junction. Bathymetric lineations with "Phoenix" trends intersect lineations with a "Line Islands" trend along this arch. If Nova-Canton Trough is a jumped PacificPhoenix Ridge that extends to a triple junction, then the Pacific-Farallon Ridge at this junction may also be a jumped ridge, although this is not a requirement of rigid plate tectonics. The failure to recognize magnetic anomalies parallel to the Hawaiian set near the Line Islands (if they are not buried by younger volcanics) could result from the Pacific-Farallon Ridge having had an unfavorable orientation for its paleolatitude during creation of the ocean crust.

The Line Islands trend meets the eastern part of the mountains at right angles. Horizon Guyot and Necker Ridge are two especially prominent features with this orthogonal orientation, but the regional (Chase et al., 1971) and the more detailed (Plate 1) bathymetric charts show many other prominent parallel lineations in and along the edges of the Mid-Pacific Mountains. These lineations are parallel to fracture zones mapped farther north in the Hawaiian magnetic anomaly lineation set (Larson and Chase, 1972; Hilde, 1974).

\section{Relation Between Line Islands Chain and the Sea Floor Farther East}

The major fracture zones east of the Line Islands chain are neither orthogonal to the chain, nor can they be traced with certainty through it. The Molokai Fracture Zone is recognizable west of the Hawaiian Islands to about $18^{\circ} \mathrm{N}, 167^{\circ} \mathrm{W}$ as a line of deeps and ridges (Plate 1); if it extends westward beyond the Line Islands, it must bend more southwesterly. The angle between the fracture zone and the Line Islands chain is about $70^{\circ}$. The Clarion Fracture Zone can be followed to the chain, but no trace of the zone can be discerned in the available soundings west of the chain. Neither is there any offset of the chain at the intersection of the two trends. The Clipperton Fracture Zone is not recognizable any farther west than about $153^{\circ} \mathrm{W}$, some $300 \mathrm{~km}$ from the Line Islands chain. The angle between the chain and the fracture zone is about $65^{\circ}$. Nova-Canton Trough does not line up directly with the Clipperton Fracture Zone.

In view of these geometrical relations, the Line Islands trend is considered to be older than the fracture zones to the east, and some limits can be put on the age of the eastern sea floor from drilling results at JOIDES Site 164 (Winterer, Ewing, et al., 1973). The age of oceanic basement at this site, located just north of the Clarion Fracture Zone about $300 \mathrm{~km}$ east of the Line Islands chain is 100-115 m.y. (Albian to Barremian). This is consistent with the age of 100-115 m.y. for the Line Islands trend required if it is a relict of the PacificFarallon spreading ridge contemporaneous with the Nova-Canton Trough, provided half-spreading rates during creation of oceanic crust now lying between Site 164 and the Line Islands chain were not slower than about $3 \mathrm{~cm} / \mathrm{yr}$. 


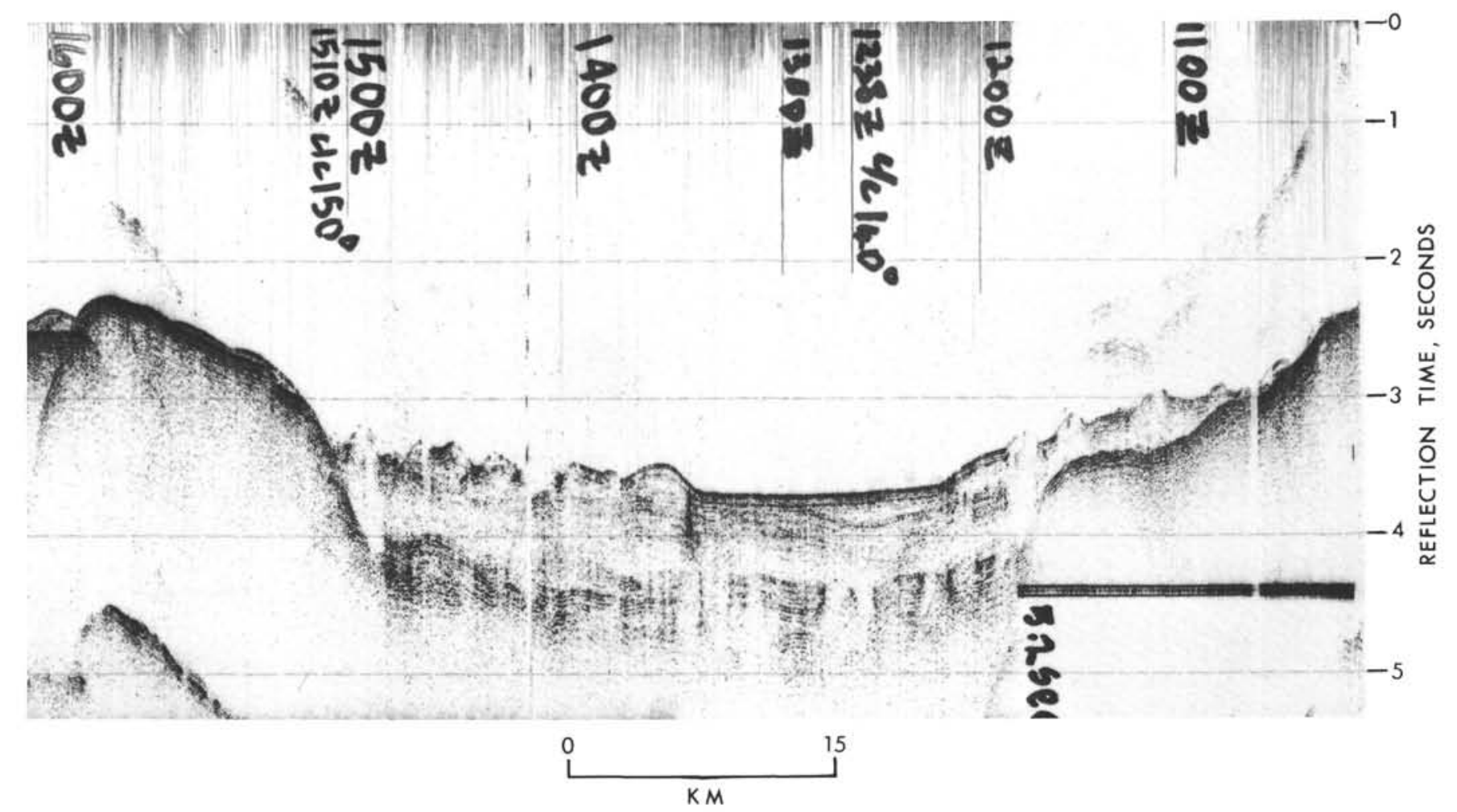

Figure 11. Seismic reflection profiler record obtained by $R / V$ Thomas Washington during Scripps Institution of Oceanography Cruise Eurydice, Leg 2, showing an intermontane valley within the Line Islands chain, between Fanning and Washington islands. The valley contains a thick fill of sediments, whereas the adjacent ridge tops are capped by only very thin sediments.

The angular relation between the fracture zones and the Line Islands trend, taken together with the age of basement at Site 164, suggests that if the Line Islands trend is the trace of the Pacific-Farallon Ridge of about 110 m.y. ago, then there was a change of orientation of that ridge sometime in the succeeding $10 \mathrm{~m} . \mathrm{y}$. to a direction more nearly orthogonal to the fracture zones.

\section{Relation Between Cross Trend and Line Islands Chain}

The model of crustal ages introduced in the preceding paragraphs does not account at all for the basement ages obtained at drill sites in the Line Islands, bathymetric lineations, nor for the basement ages obtained at JOIDES drill sites in this band of lineated topography. The region showing lineations parallel to the Cross Trend extends westward from the Line Islands in a broad belt lying between Jarvis Island on the south and the Mid-Pacific Mountains on the north (Winterer, 1973a, Plate 1). Other Cross Trend seamount chains may be recognizable much farther south (e.g., Phoenix Islands-Penrhyn Island) and north (e.g., Musician Seamounts).

In the Central Basin west of the Line Islands, three general types of terrain can be recognized in the Cross Trend: first, narrow ridges and lines of seamounts like those close to the Line Islands chain; second, broad mounds, similar on a smaller scale to Magellan Rise in their morphology and thick sediment cover; and third, deep $(>6000 \mathrm{~m})$ troughs, commonly associated with step-downs (faults?) in the basement (Raff, 1973, profile $\mathrm{S} 21,0800 \mathrm{hr}$ ). The basement in the deep water parts of the Cross Trend is relatively smooth over long stretches (Raff, 1973, profiles 21, 22, 24, 26) broken by sharp ridges and seamounts and by step faults. Near the Marshall Islands and JOIDES Site 169, this terrain gives way to a region with an even smoother basement (Raff, 1973, profiles 19 and 20 ).

The age of oceanic crust in the Cross Trend region is questionable. If one simply extrapolates northward from the Phoenix magnetic lineations, using the date obtained by drilling on Magellan Rise ( 130 m.y.) (Winterer, Ewing, et al., 1973) and magnetic anomalies older than M-20 recently identified (R. Larson, personal communication) just east of the Marshall Islands and only about $100 \mathrm{~km}$ south of JOIDES Site 169 , then an age of earliest Cretaceous or Late Jurassic is deduced. But JOIDES Sites 169 and 170, drilled in or next to the Cross Trend, on the contrary, recovered Albian limestone resting on basalt at both sites (Winterer, Ewing, et al., 1973). At Site 169, the basalt is tholeiitic, like that on oceanic spreading ridges (Bass et al., 1973), and the contact between sediments and basalt is depositional. At Site 170, which is most clearly within the belt of Cross Trend topography, the "basement" basalt was highly altered, and is not unequivocally assigned to a class of basalts by Bass et al., though they favored ocean-island or alkali basalt over ocean ridge tholeiite. Based on textural evidence and the lack of either glass or pillow structure, Bass et al. interpreted this basalt as a sill. As 


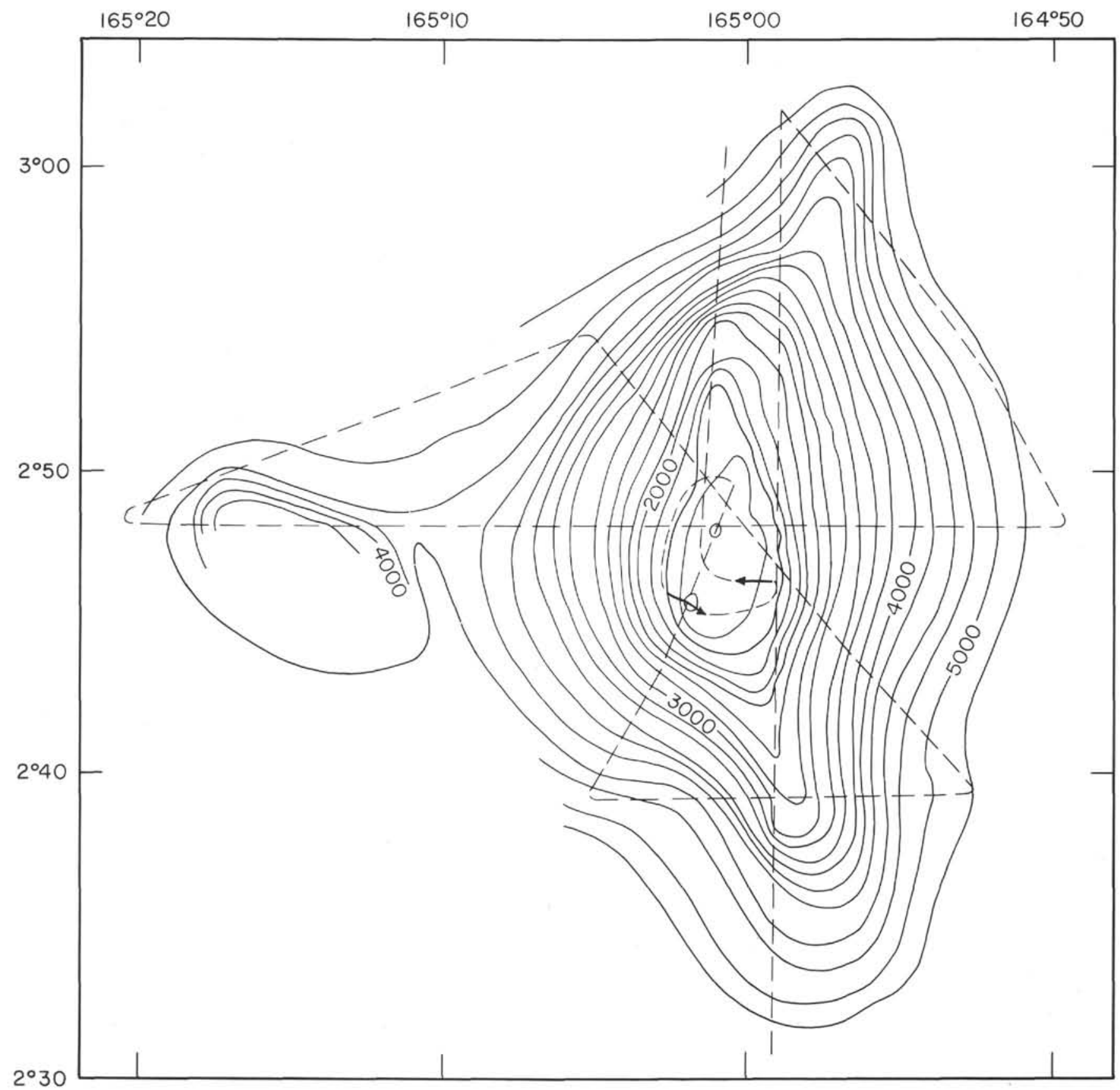

Figure 12. Bathymetric chart of a seamount in a Cross Trend chain about $100 \mathrm{~km}$ northeast of DSDP Site 66, surveyed by $R / V$ Thomas Washington during Scripps Institution of Oceanography Cruise Seven-Tow, Leg 6. Two dredges, taken at the locations indicated by the arrow (Stations $118 \mathrm{D}$ and 119D) contained hawaiite, mugearite, and hyaloclastites (Natland, this volume), and, in a breccia of volcanic and limestone clasts, planktonic foraminifers of (?) Miocene age, according to Matthews' tables (1944). Ship's track shown by dashed lines.

reviewed previously (Winterer, 1973b), reflection profiler data suggest that as much as 150 meters of sediments may lie unsampled beneath the "basement" at Site 170 . Finally, even younger sills were drilled at both Sites 169 (<87-100 m.y.) and 170 (<80-87 m.y.).

Two contrasting models are thus available:

1) The Cross Trend features were produced during one or more periods of mid-plate volcanism that flooded an older (Early Cretaceous-Late Jurassic) oceanic crust that lay close to the bight between the Phoenix and
Hawaiian lineations. The old crust may have escaped flooding locally, as on the shallow mounds and here and there on the deep sea floor, where seismic profiler records show relatively thicker sediments than were drilled at Site 170. In this model, the mid-plate volcanism occurred at least twice in this region, once about 103 m.y. ago, producing the basement at Site 169-perhaps associated with the construction of the adjacent part of the Marshall Island chain-and the older sill (?) at Site 170, and then again in Late 
Cretaceous times. Whether the younger sills at Sites 169 and 170 are synchronous is unknown. If they were intruded close to the sea floor, the age of the young sill at Site 169 would be about $87-95$ m.y. and at Site 170 about 80-87 m.y. The Albian mid-plate volcanism not only buried at least some of the older oceanic crust, but probably also masked magnetic anomalies in the older crust. At least a modest amount of general regional uplift associated with the Albian mid-plate volcanism is implied by the basal limestone at Sites 169 and 170, although the difference in age between the oceanic crust $(\sim 140$ m.y. ?) and the mid-plate volcanism ( 105) places Site 170 at a paleodepth of only about 4600 meters (Sclater et al., 1971).

What produced the Cross Trend lineations is not at all clear. If the volcanism associated with the younger sills was progressive from west to east, then the similarity in the age of the sill at Site 170 (80-87 m.y.) and of cessation of volcanism at Site 165 ( $\sim 85$ m.y.) raises the same problems as in the Line Islands: very fast progression. A more attractive hypothesis would allow nearly simultaneous eruption of basalt over a broad region by having numerous relatively short progressive chains operating in parallel.

In this model, the Line Islands chain itself, with its internal Cross Trend en echelon structure could be interpreted as simply the intersection of many relatively short parallel Cross Trend chains with some older structure (the 110 m.y.-old trapped Pacific-Farallon (?) Ridge), where previous tectonism provided easier access to the surface for lavas, and thus permitted more voluminous extrusions along that line than elsewhere. If the Line Islands trend were an old jumped ridge, then the special conditions for voluminous mid-plate volcanism might include a high residual heat flow, such as characterizes some Cenozoic jumped ridges (Herron, 1972). The near simultaneity in the cessation of volcanism at Sites 165, 315 , and 316 would imply volcanism proceeding simultaneously along three parallel Cross Trend lines extending west-northwest from the three drill sites. Sites 315 and 316 are only about $200 \mathrm{~km}$ apart, measured along the Cross Trend, whereas Sites 315 and 165 are about $800 \mathrm{~km}$ apart, along the same direction. Thus some chains were proceeding abreast of one another, while others trailed. The possibility that young mid-plate extrusives may follow older tectonic lines is not unique to the Line Islands. Possible examples can be found in the Musician Seamounts, in the northeast Pacific near the Sila Fracture Zone, and on a smaller scale, perhaps even in the Hawaiian Chain, where the en echelon loci of volcanism (Jackson et al., 1972) tend to line up with the isochrons on the subjacent ocean crust.

2) In the other model for the origin of the Cross Trend, it represents a band of oceanic crust produced during a short-lived episode of sea-floor spreading in the Central Basin. In favor of this model is the fact that upper Albian limestone overlies basalt at Sites 169 and 170 in the Central Basin. Site 170 remained mainly above the compensation depth for calcium carbonate for about 30 m.y. (Winterer, 1973b, fig. 4), implying a relatively shallow $(\sim 3 \mathrm{~km})$ sea-floor depth during Albian times, and in keeping with an origin at an oceanic rise crest.
The total amount of spreading on this ridge would be small (the total width of the Central Basin measured between Magellan Rise and the Mid-Pacific Mountains is only $1000 \mathrm{~km}$ ), and the width could be very much less if the plateau-like areas in the Central Basin are relicts of older oceanic crust. Fracture zones are required in this model along the west side of Magellan Rise, and very many are required within the Line Islands as well, in order to keep stepping the Cross Trend pattern to the southwest. A serious objection to this model is that virtually no evidence for these fracture zones in the Line Islands can be found in the bathymetry or in seismic profiler records. The conspicuous deep-water region trending north-northeast at the southern tip of the Line Islands chain, near Malden Island, could represent a fracture zone in this set, perhaps continuing farther south into the Penrhyn Basin, parallel to the abrupt eastern escarpment of the Manihiki Plateau.

The timing of spreading in this second model $(\sim 105$ m.y. ago) is nearly synchronous with the generation of Manihiki Plateau, and a complex triple junction would be required to connect that system with the Cross Trend spreading ridge. Since the direction of spreading on the Pacific-Phoenix Ridge changed markedly from the Phoenix-Canton direction to the Manihiki direction about 105-110 m.y. ago, it would not be unreasonable to expect other reorientations of Pacific spreading ridges at this time.

Since the Line Islands (at Sites 315, 316, and 165) volcanism is younger than any of this spreading, the Line Islands trend itself would have to postdate the MidCretaceous Central Basin spreading. Under this model, the younger Line Islands volcanism would have partly used old Cross Trend directions, thus accounting for the strong en echelon Cross Trend arrangement of ridges within the Line Islands chain. The Cross Trend chains that extend from the south end of the Line Island Ridge through Jarvis Island and JOIDES Site 66 are completely unexplained in this model. Alternatively, the en echelon pattern results from some net stress field in the lithospheric plate, as Jackson and Shaw (in press) have hypothesized for the en echelon pattern of subchains in the Hawaiian chain. In this case, the parallelism with the Cross Trend is either fortuitous, or the Cross Trend is of the same general age as the Line Islands and represents a response to the same stress field that operated to produce the cracks for magma streaming in the Line Islands.

Another model, which is actually a variant of the second model, would have the Line Islands chain mark the site of a long set of cracks through the lithosphere in a direction parallel to the spreading direction on the Pacific-Farallon Ridge about 85 m.y. ago. This feature would constitute what amounts to an incipient rise crest, cracking an older piece of crust just enough to allow extrusion of lavas to form narrow ridges, many of which would be constructed along the older Cross Trend direction. After only a few million years of incipient opening (like the Mid-African rifts), volcanism ceased. This model encounters three difficulties, two of which may be fatal: (1) The spreading direction 85 m.y. ago was probably much more east-west than the Line Islands 
Ridge, if the trends of northeast Pacific Fracture Zones near anomaly 33 can be taken as indicating the spreading direction at that time; (2) The petrology of the Line Islands basalts is like that on mid-plate island chains and not at all like that on oceanic rises (Jackson et al., this volume), although it is conceivable that the special environment of incipient or very slow spreading on much older crust might lead to lavas somewhat different from abyssal tholeiites; and (3) there is no explanation for the chains of Cross Trend seamounts in areas not immediately adjacent to the Line Islands.

One final model, of course, is the original Morgan model, in which the Line Islands chain is simply a progressive mid-plate volcanic chain of the Hawaiian type, that crosses another set of Hawaiian-type chains-the Cross Trend-at an angle. The pervasive en echelon Cross Trend features within the Line Islands are in this hypothesis the result of overprinting of one direction on the other. In this model, the age relations between the two directions of propagation could be any of the three possibilities: Line Islands older than Cross Trend, Line Islands younger than Cross Trend, or Line Islands the same age as Cross Trend. The great length of both sets of chains makes the last possibility unlikely. The drilling results at Sites 170 and 66, both in the Cross Trend, give dates older than those along the Line Islands, at Sites 165,315 , and 316 , leaving us with the choice that the Line Islands chain postdates the Cross Trend. The near simultaneity in cessation of volcanism at Sites 165,315 , and 316 argues for an extraordinarily fast rate of propagation of volcanism along the chain and makes it difficult to accept the chain as being of the Hawaiian type. A final difficulty with this model is the trend of the Line Islands chain, which is very difficult to fit with any other set of chains in the Pacific. The Emperor and Marshall-Gilbert-Ellice groups, which come closest to parallelism with the Line Islands, are probably mainly early Cenozoic in age, and no other Late Cretaceous chains concentric with the Line Islands are known on the Pacific plate. These arguments are not necessarily fatal, but they pose serious difficulties to acceptance of the progressive volcanic chain model.

The model subject to the most uncertainty is that requiring short-lived Mid-Cretaceous spreading in the Central Basin, to form the ground plan of the Cross Trend. The difficulties in placing fracture zones so as to include all the Cross Trend features and still keep the band of spreading of nearly constant width are almost insurmountable when the problem is looked at in detail. It seems more likely that a system of parallel volcanic chains, perhaps along extensive slow-opening cracks, will account for the morphology, petrology, and age relations in the Central Basin. The earliest (early Albian) period of mid-plate volcanism would have flooded the old basement, and a later period of seamount and ridge building, along many parallel lines-perhaps inherited from the Albian-accounts for the Cross Trend Ridges. Isolated shallow mounds between Magellan Rise and the Mid-Pacific Mountains may be remnants of the "true" oceanic crust in this belt.

The difficulties in requiring the Cross Trend chains to coalesce in the Line Islands chain along an old (Early
Cretaceous) spreading direction are not trivial, but they may not be fatal. Precious few examples of a similar palimpsest relation between young volcanism and old structure can be documented. Some special circumstance, such as an old jumped ridge-the Hawaiian lineation equivalent of the Nova-Canton Trough-must be invoked to create the special "leaky" conditions required to cause volcanism along the Cross Trend chains to spread out and be more voluminous along the Line Islands chain. It is interesting that the highest-standing and widest part of the Line Islands chain is across the shallow arch that is the supposed bight between the Phoenix-Canton and Hawaiian lineations, just where the extra thickness of old crust might be expected to inhibit younger volcanism. If we turn to Nova-Canton Trough itself, we find, in addition to the Cross Trend chain that appears to spread out along the trough, several other examples of volcanic chains, such as the Gilbert-Ellice and Tokelau groups, crossing the trough with no noticeable tendency to spread out along it (Mammerickx et al.,1974, Sheet 12). These crossings are at right angles and may even be along old fracture zones of the Phoenix lineation system, but the fact remains that they do not tend to form ridges along the old NovaCanton line. The age difference between the NovaCanton and the Gilbert-Ellice trends may be very great, if the Gilbert-Ellice are a part of the early Cenozoic midplate volcanism parallel with the Emperor Seamount chain. Any "booster" effect of residual high heat flow at the jumped ridge may have dissipated in the 40-70 m.y. between the two volcanic episodes.

On balance, the fewest differences are associated with the model in which the Line Islands chain is built in Late Cretaceous times over the site of an Early Cretaceous ridge-perhaps a jumped ridge-by numerous parallel Cross Trend seamount chains-possibly progressive-that poured out unusual volumes of lava where the chains crossed the old ridge.

\section{Implications of Palimpsest Model}

If this model is more or less correct, then the direction of Pacific plate motion over the asthenosphere about 85 m.y. ago would be most likely given by the Cross Trend, and not by the Line Islands Trend. The slight bend at the north end of the Emperor Seamount chain, at Meiji Guyot, may mark the transition from "Cross Trend" to "Emperor" direction of plate motion about 70 years ago, near the end of the Cretaceous. Seamount chains with a Cross-Trend orientation are well developed between the Marshall Islands and the Mariana-BoninJapan Trench system. It is noteworthy that flat-topped seamounts in these chains near Japan yield Middle Cretaceous reef fossils (Heezen et al., 1973) and give excellent paleomagnetic pole positions suggesting they formed during the Mid-Cretaceous magnetic quiet period. The transition between Late Cretaceous Cross Trend direction of plate motion and the early Cenozoic Emperor direction may be reflected in the several broad congruent bands that link the chains of the Marshall Islands, which are at least partly of early Cenozoic age (Emery et al., 1954; Schlanger, 1963; Kulp, 1963), with the Cross Trend chains extending west-northwest from 
Eniwetok and Wake islands. The rate of motion of the Pacific plate over Cross Trend melting anomalies can be only roughly estimated by assuming that the deep water volcanism in the Central Basin dated at early Albian (102-104 m.y.) at Site 170 is part of a progressive system that arrived beneath the Line Islands near Site 165 about $85 \mathrm{~m} . \mathrm{y}$. ago, giving an average rate over the $2100 \mathrm{~km}$ of about $11 \mathrm{~cm} / \mathrm{yr}$.

A further implication of the Cross Trend direction of plate versus melting anomaly motion in Mid-Cretaceous times is that the latitudinal motion of the plate in that frame of reference would have been very slight during that time. Of course, the latitudinal motion in the Pacific versus Antarctic plate frame of reference may have been considerable, if Antarctica was held essentially fixed over the South Pole. Paleolatitude reconstructions must take into account motions in both frames of reference, unless the asthenosphere is regarded as fixed with respect to the spin axis of the earth.

The implication of the model for volcanism along the Line Islands chain is that the time of beginning and cessation of volcanism on any segment along the chain depends on the progress of volcanism along the Cross Trend chain that crosses the Line Islands chain in that area. If the Cross Trend chains were progressing exactly abreast of one another, there would be a progression of dates of older to younger from north to south along the Line Islands, but there is not reason to impose this restriction on Cross Trend chains. Thus, the inception of volcanism might be in mixed order, or even simultaneous along the Line Islands, and since the final stages of mid-plate volcanism may postdate the initial stages by a variable length of time up to several million years, then the scatter of ages obtained by dating seamounts or final lavas might be fairly large.

\section{Summary of Tectonic History}

The sequence of events in the plate tectonic evolution and later volcanic history of the Central Pacific through the formation of the Line Islands chain is summarized diagrammatically in Figures 13-15, beginning about 110 m.y. ago with a triple junction among the PacificPhoenix, the Pacific-Farallon, and the Farallon-Phoenix spreading ridges close to the present location of Christmas Island (Figure 13), followed soon after by a southward shift and reorientation of the Pacific-Phoenix Ridge (Figure 14) that resulted in the abandonment of the old ridge at Nova Canton Trough and the trapping of a piece of Phoenix plate between the trough and the new spreading ridge on Manihiki Plateau. The triple point shifted southward, perhaps accompanied by an abandonment of the old Pacific-Farallon Ridge along the site of the Line Islands, perhaps only by an extension southward of this ridge while spreading continued (this more conservative version is shown in Figure 14). After another 5 m.y. (Figure 15), the triple point again shifted south, possibly to the vicinity of Palmerston Island, and spreading directions were again reoriented. On the Pacific-Farallon Ridge, the new direction is given by the trend of the Molokai, Clarion, and Clipperton fracture zones near the Line Islands. The shift of the Pacific-
Phoenix Ridge at this time abandoned the older spreading centers on Manihiki Plateau and again trapped pieces of old Phoenix plate on the Pacific plate south of Manihiki Plateau (Winterer et al., 1974).

At about this same time, about 105 m.y. ago, midplate volcanism was building several chains of volcanoes across the Central Basin area, with an orientation reflecting the direction of motion of the plate over subjacent melting anomalies in the asthenosphere (Figure 15). There were probably chains not only in the Central Basin, but also farther west, between the present-day Marshall Islands and the Bonin Trench. Lavas were extruded in deep water as well as being emplaced in seamounts. The major loci of volcanism are concentrated near the old bight between the Jurassic and Early Cretaceous spreading ridges, in a region spotted with old plateaus and shallow areas. The peculiar composition of volcanic rocks in the Cross Trend chain(Natland, this volume) may reflect the presence of an extra thick crust generally associated with plateaus. The volcanoes of the Mid-Pacific Mountains may also have had most of their growth at this time, but it is possible that they were constructed atop an already somewhat shallow plateau region close to the Late Jurassic and Early Cretaceous triple junction (Figure 13). The motion of the plate over the melting anomalies brought the loci of mid-plate volcanism to the site of the $110 \mathrm{~m} . \mathrm{y}$. old Pacific-Farallon spreading ridge-the Line Islands chain-about 85 m.y. ago, and owing to some special features of the crust along this line-perhaps deep fractures and/or high residual heat flow associated with an abandoned ridge crest-great volumes of volcanic rocks were emplaced along these older structural trends, to form the Line Islands seamounts and ridges.

The Cross Trend volcanism continued eastward past the Line Islands, but these melting anomalies faded away sometime before about 70 m.y. ago, when there was a change in the direction of motion of the Pacific plate (over melting anomalies) from the Cross Trend direction to the Emperor Seamount chain direction. This change in direction is not recorded near the Line Islands, but can be seen in the angle between the Cross Trend chains and the Marshall Island chains.

\section{ACKNOWLEDGMENTS}

A great number of colleagues and students have participated with me in cruises to the Line Islands region, and I am grateful to each of them for contributing to the collection of geologic and geophysical data and for their role in shaping my own ideas about the significance of the data. The late Edwin C. Allison was especially instrumental in focusing my attention on the several intersecting tectonic trends in the region; his reputation as a first-rate paleontologist tended to draw attention away from his abilities as a regional structural geologist. I am especially indebted to J. Natland and R. Jarrard, who began their Line Islands petrologic and magnetic studies in 1971 , and who have generously given of their time and data in our many discussions of regional problems. I am grateful for the help and constructive criticism of many others, including J.L. Matthews, S.O. Schlanger, E.D. Jackson, R. Moberly, Jr., J. Ewing, J. Keene, P. Lonsdale, D. Clague, B. Rosendahl, and A. Bosellini. 


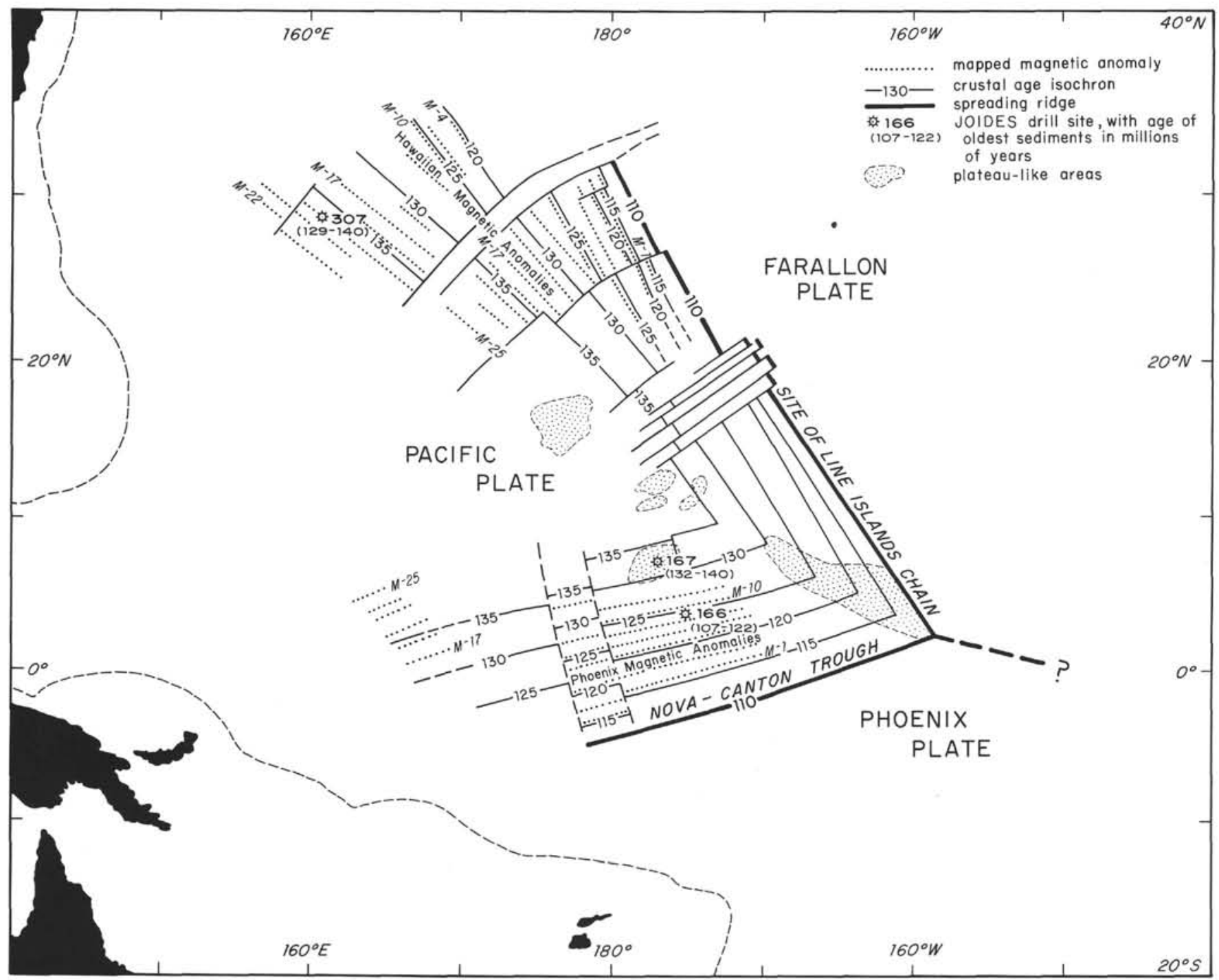

Figure 13. Configuration of plates in the Central Pacific about $110 \mathrm{~m} . y$. The Pacific and Phoenix plates were separated by a spreading ridge at the present-day location of Nova-Canton Trough, and the Pacific and Farallon plates were separated by a spreading ridge at the present-day location of the Line Islands chain. Magellan Plateau and other anomalously shallow areas formed during Late Jurassic and Early Cretaceous times in the vicinity of the bight between the two spreading ridges. Magnetic anomalies (from Pitman et al., 1974) are shown as dotted lines. Ages at JOIDES drill sites 166 and 167 from Winterer, Ewing, et al., 1973; at Site 307 from JOIDES Scientific Staff, 1973b. Assignment of ages in the magnetic anomaly regions adjusted for an even spreading rate from Site 167 to the Nova-Canton Trough. Isochrons and fracture zones in areas beyond mapped magnetic anomalies were extrapolated largely on the basis of bathymetric trends.

\section{REFERENCES}

Bass, M.N., Moberly, R., Jr., Rhodes, J.M., Shih, C., and Church, S.E., 1973. Volcanic rocks cored in the Central Pacific, Leg 17, Deep Sea Drilling Project. In Winterer, E.L., Ewing, J.I., et al., Initial Reports of the Deep Sea Drilling Project, Volume 17: Washington (U.S. Government Printing Office), p. 429-503.

Chase, T.E., Menard, H.W., and Mammerickx, J., 1971. Topography of the North Pacific (Chart TR-17): Institute of Marine Resources, University of California at San Diego.

Emery, K.O., Tracey, J.I., Jr., and Ladd, H.S., 1954. Geology of Bikini and nearby atolls: U.S. Geol. Surv. Prof. Paper 260-A, p. 1-265.

Heezen, B.C., Matthews, J.L., Catalano, R., Natland, J., Coogan, A., Tharp, M., and Rawson, M., 1973. Western
Pacific guyots. In Heezen, B.C., MacGregor, I., et al., Initial Reports of the Deep Sea Drilling Project, Volume 20: Washington (U.S. Government Printing Office), p. 653723.

Herron, E.M., 1972. Sea-floor spreading and the Cenozoic history of the east-central Pacific: Geol. Soc. Am. Bull., v. 83 , p. 1671-1692.

Hilde, T.W.C., 1974. Mesozoic sea-floor spreading in the North Pacific: D.Sc. thesis, University of Tokyo (unpublished manuscript).

Jackson, E.D., in press. Linear volcanic chains in the Pacific Basin. In Sutton, G. (Ed.), Am. Geophys. Union Monograph: International Woollard Symposium on the Geophysics of the Pacific Ocean Basin and its Margin.

Jackson, E.D., Silver, E.A., and Dalrymple, G.B., 1972. Hawaiian-Emperor chain and its relation to Cenozoic cir- 


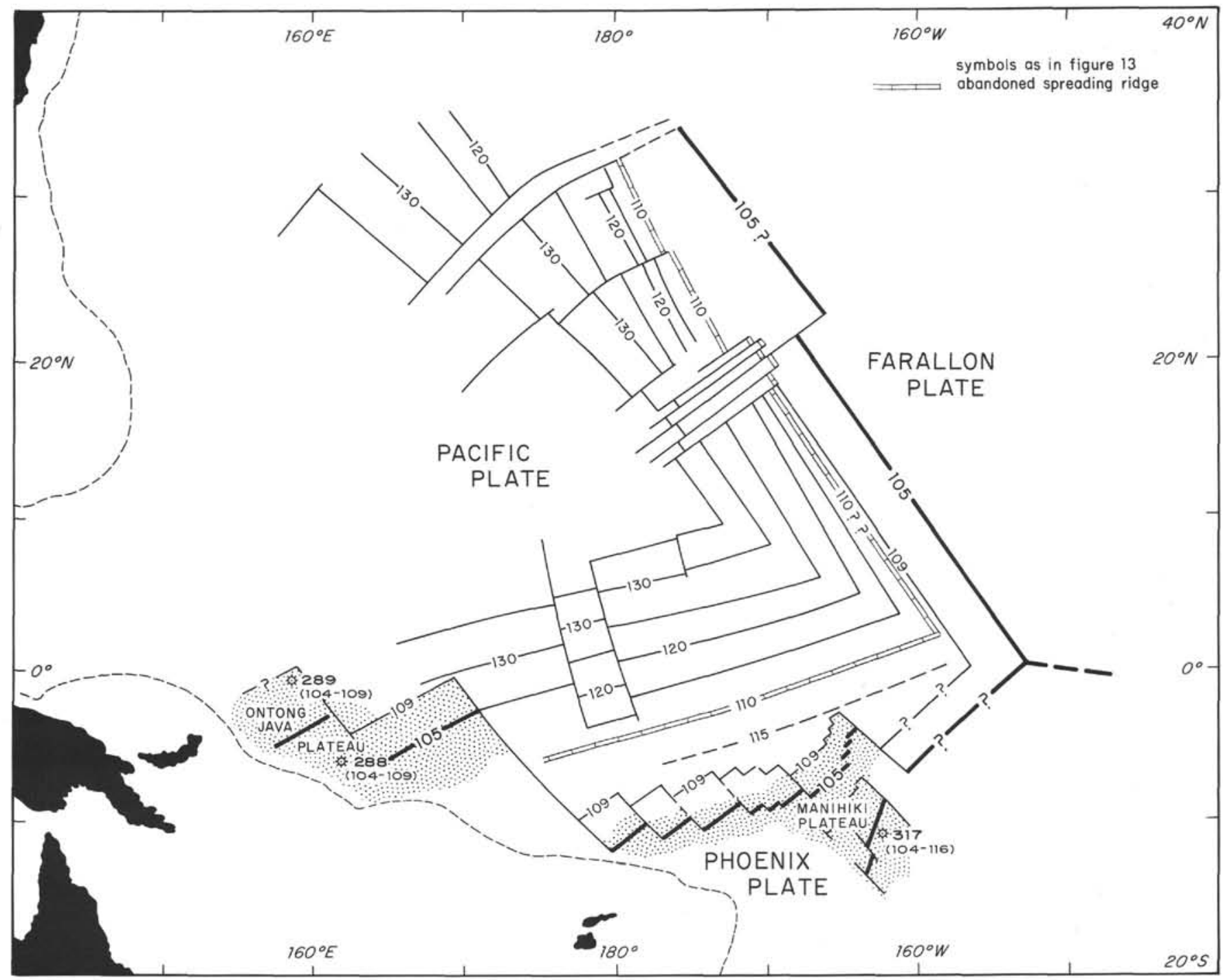

Figure 14. Configuration of plates in the Central Pacific about 105 m.y. The former spreading ridge at Nova-Canton Trough was abandoned during a change in orientation of the Pacific-Phoenix spreading ridge. The new ridge was located on the Manihiki Plateau, but its connections to the Pacific-Farallon Ridge are not known. There may have been a small extra plate on part of the Manihiki Plateau. The history along the Pacific-Farallon Ridge during this time is not known. In the version shown here spreading continued, with perhaps a change in rate at about $110 \mathrm{~m} . y$., but the alternative of a jump in the Pacific-Farallon Ridge at this time is also possible. Ages at JOIDES drill sites from this volume and from JOIDES Scientific Staff, 1973a.

cumpacific tectonics: Geol. Soc. Am. Bull., v. 83, p. 601618.

JOIDES Scientific Staff, 1973a. Leg 30. Deep Sea Drilling Project: Geotimes, v. 18, p. 18-21.

JOIDES Scientific Staff, 1973b. Leg 32. Deep Sea Drilling Project: Geotimes, v. 18, p. 14-17.

Kulp, J.L., 1963. Potassium-argon dating of volcanic rocks: Bull. Volcanol., v. 26, p. 247-258.

Larson, R.L. and Chase, C.G., 1972. Late Mesozoic evolution of the western Pacific Ocean: Geol. Soc. Am. Bull., v. 83, p. 3627-3644.

Larson, R.L., Smith, S.M., and Chase, C.G., 1972. Magnetic lineations of Early Cretaceous age in the western equatorial Pacific Ocean: Earth Planet. Sci. Lett., v. 15, p. 315-319.

Mammerickx, J., Smith, S.M., Taylor, I.L., and Chase, T.E., 1974. Bathymetry of the south Pacific (Chart 13): Institute of Marine Resources, University of California at San Diego.
Matthews, D.J., 1944. Tables of the velocity of sound in pure water and sea water for use in echo-sounding and soundranging: Hydrogr. Dept., Admiralty, H.D. 282 (2nd ed).

Morgan, W.J., 1972a. Deep mantle convection plumes and plate motion: Am. Assoc. Petrol. Geol. Bull., v. 56, p. 203213.

1972b. Plate motions and deep mantle convection: Geol. Soc. Am. Mem. 132, p. 7-22.

Natland, J., Lonsdale, P.F., and Winterer, E.L., 1972. Possible caldera collapse on seamounts in the Line Islands: Geol. Soc. Am. Abstracts with Program, v. 4, p. 207-208.

Normark, W.R. and Spiess, F.N., in press. Erosion in the Line Islands archipelagic apron: Geol. Soc. Am. Bull.

Pitman, W.C., III, Larson, R.L., and Herron, E.M., 1974. Magnetic Lineations of the Oceans (Map): Boulder, (Geol. Soc. Am.).

Raff, A., 1973. Underway data. In Winterer, E.L., Ewing, J.I., et al., Initial Reports of the Deep Sea Drilling Project, 


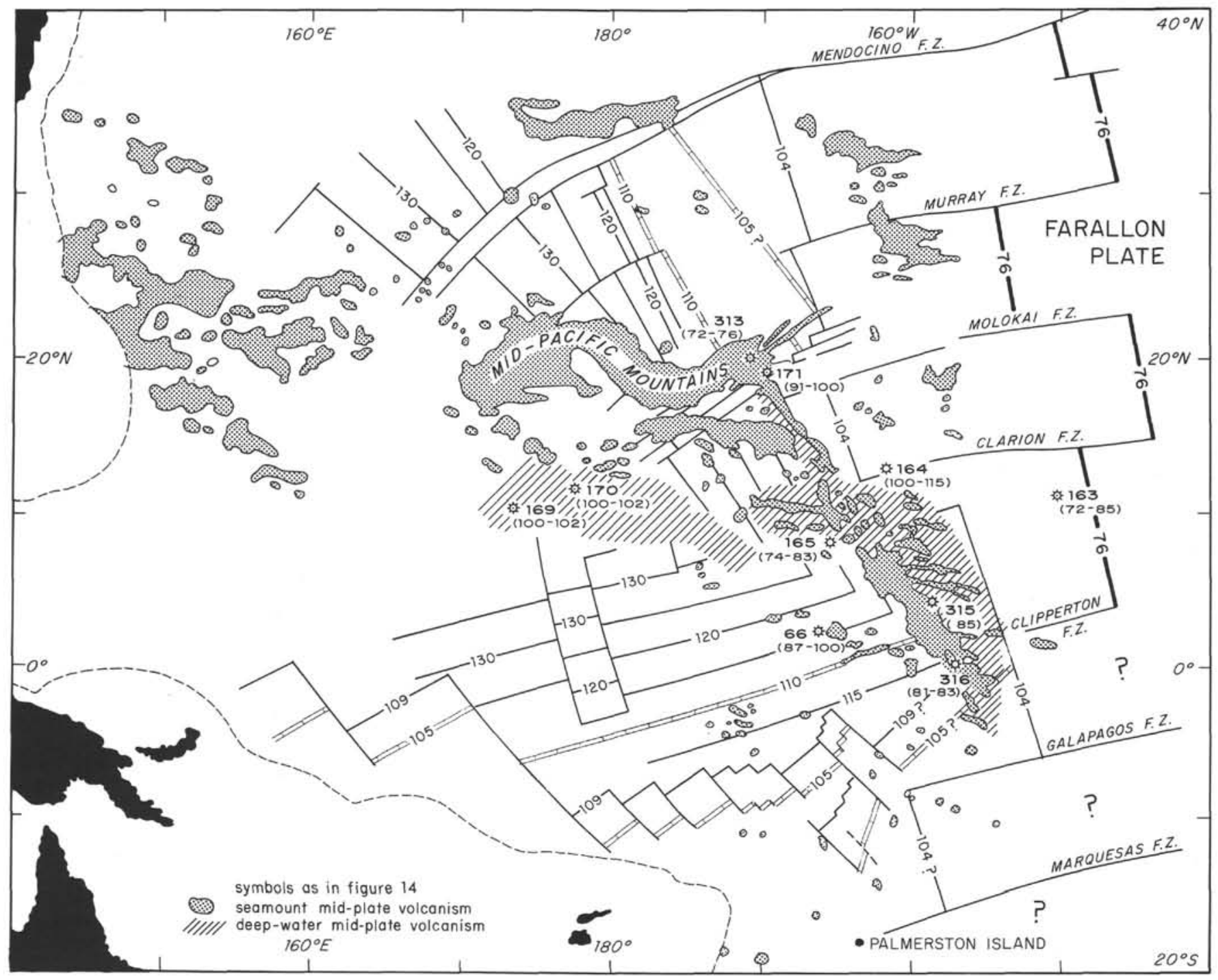

Figure 15. Configuration of plates in the Central Pacific about 76 m.y. (anomaly 32 time). A reorientation of spreading direction on the Pacific-Farallon and Pacific-Phoenix (Antarctic) ridges about 105 m.y. ago stranded the old ridges on Manihiki Plateau. The new triple junction moved south, probably to the vicinity of Palmerston Island. Spreading on the PacificFarallon Ridge between 105 and 75 m.y. ago probably included ridge-crest jumping, but the location and timing of these events is not yet known. Between about 105 and 85 m.y. ago, mid-plate volcanism built chains of Cross Trend seamounts in a broad band trending west-northwest from the Line Islands to the Bonin Trench. Lavas of this age were extruded in deep water over large regions in the Central Basin and around the Line Islands. The volcanism was probably progressive, propagating toward the east-southeast along parallel lines. Where Pacific plate motion carried the old Line Islands Spreading Ridge over the Cross-Trend melting anomalies, the lavas tended to be guided by older structural trends. The older crust in the Line Islands area is thus mainly buried beneath younger volcanics. Ages at JOIDES drill Site 66 from Winterer, Riedel, et al., 1971; at Site 163 from van Andel, Heath, et al., 1973; at Sites 164, 165, 169, 170, and 171 from Winterer, Ewing, et al., 1973; at Site 313 from JOIDES Scientific Staff, 1973b; and at Sites 315 and 316 from this volume.

Volume 17: Washington (U.S. Government Printing Office), p. 337-364.

Rosendahl, B.R., 1972. Geological and geophysical studies of the Canton Trough and surrounding regions: M.S. Thesis, University of Hawaii, Honolulu (unpublished manuscript).

Schlanger, S.O., 1963. Subsurface geology of Eniwetok atoll: U.S. Geol. Surv. Prof. Paper 260-BB, p. 991-1065.

Sclater, J.G., Anderson, R.N., and Bell, M.L., 1971. The elevation of ridges and the evolution of the central eastern Pacific: J. Geophys. Res., v. 76, p. 7888-7915.

van Andel, T.H., Heath, G.R., et al., 1973. Initial Reports of the Deep Sea Drilling Project, Volume 16: Washington (U.S. Government Printing Office).

Winterer, E.L., 1973a. Bathymetric chart of the Central Pacific Basin. In Winterer, E.L., Ewing, J.I., et al., Initial
Reports of the Deep Sea Drilling Program, Volume 17: Washington (U.S. Government Printing Office). 1973b. Regional Problems. In Winterer, E.L., Ewing, J.I., Initial Reports of the Deep Sea Drilling Program, Volume 17: Washington (U.S. Government Printing Office), p. 911-922.

Winterer, E.L., Riedel, W.R., et al., 1971. Initial Reports of the Deep Sea Drilling Project, Volume 7: Washington (U.S. Government Printing Office).

Winterer, E.L., Ewing, J.I., et al., 1973. Initial Reports of the Deep Sea Drilling Project, Volume 17: Washington (U.S. Government Printing Office).

Winterer, E.L., Lonsdale, P.F., Matthews, J.L., and Rosendahl, B.R., 1974. Structure and acoustic stratigraphy of the Manihiki Plateau: Deep-Sea Res., v. 21, p. 793-814. 